\title{
Review \\ Obesity and Androgen Receptor Signaling: Associations and Potential Crosstalk in Breast Cancer Cells
}

\author{
Nelson Rangel ${ }^{1, * \mathbb{D}}$, Victoria E. Villegas ${ }^{2, * \mathbb{D}}$ and Milena Rondón-Lagos ${ }^{3}$ (D) \\ 1 Departamento de Nutrición y Bioquímica, Facultad de Ciencias, Pontificia Universidad Javeriana, \\ Bogotá 110231, Colombia \\ 2 Centro de Investigaciones en Microbiología y Biotecnología-UR (CIMBIUR), Facultad de Ciencias Naturales, \\ Universidad del Rosario, Bogotá 11001000, Colombia \\ 3 School of Biological Sciences, Universidad Pedagógica y Tecnológica de Colombia, Tunja 150003, Colombia; \\ sandra.rondon01@uptc.edu.co \\ * Correspondence: rangeljne@javeriana.edu.co (N.R.); victoria.villegas@urosario.edu.co (V.E.V.); \\ Tel.: +57-1-318-508-7624 (N.R.); +57-1-297-0200 (ext. 4029) (V.E.V.); Fax: +57-1-297-0200 (V.E.V.)
}

check for updates

Citation: Rangel, N.; Villegas, V.E.; Rondón-Lagos, M. Obesity and Androgen Receptor Signaling: Associations and Potential Crosstalk in Breast Cancer Cells. Cancers 2021, 13, 2218. https://doi.org/10.3390/ cancers13092218

Academic Editor: Sandra Gessani

Received: 15 February 2021

Accepted: 3 April 2021

Published: 6 May 2021

Publisher's Note: MDPI stays neutral with regard to jurisdictional claims in published maps and institutional affiliations.

Copyright: (c) 2021 by the authors. Licensee MDPI, Basel, Switzerland. This article is an open access article distributed under the terms and conditions of the Creative Commons Attribution (CC BY) license (https:/ / creativecommons.org/licenses/by/ $4.0 /)$.
Simple Summary: Despite increased information showing obesity is an important breast cancer (BC) risk factor, the mechanisms implicated in this association are not well understood. In this review we describe multiple lines of evidence indicating that altered secretion of androgens and adipokines, from dysfunctional adipose tissue, are independently linked with BC development. However, adipokines (adiponectin and leptin) participate in important biological processes in BC cells by modulating signaling pathways similar to those used by the androgen receptor. These similarities suggest that crosstalk between these factors can occur, with a high probability that its interactions may be responsible for modifying the behavior of normal and tumor cells, especially in obesity. The knowledge of how adiponectin and leptin can interact with the androgen receptor signaling may prospectively guide the development of therapeutic approaches aimed at potentiating the inhibitory actions of adiponectin and androgen receptor or interfering with the pro-stimulatory role of leptin in BC.

Abstract: Obesity is an increasing health challenge and is recognized as a breast cancer risk factor. Although obesity-related breast cancer mechanisms are not fully understood, this association has been linked to impaired hormone secretion by the dysfunctional obese adipose tissue (hyperplasic and hypertrophic adipocytes). Among these hormones, altered production of androgens and adipokines is observed, and both, are independently associated with breast cancer development. In this review, we describe and comment on the relationships reported between these factors and breast cancer, focusing on the biological associations that have helped to unveil the mechanisms by which signaling from androgens and adipokines modifies the behavior of mammary epithelial cells. Furthermore, we discuss the potential crosstalk between the two most abundant adipokines produced by the adipose tissue (adiponectin and leptin) and the androgen receptor, an emerging marker in breast cancer. The identification and understanding of interactions among adipokines and the androgen receptor in cancer cells are necessary to guide the development of new therapeutic approaches in order to prevent and cure obesity and breast cancer.

Keywords: obesity; breast cancer; androgens; androgen receptor; adipokines; adiponectin; leptin

\section{Introduction}

Breast cancer (BC) is the leading cause of death from cancer in women worldwide [1]. Furthermore, obesity is currently viewed as a major global health challenge and has been confirmed by the International Agency for Research on Cancer as a BC risk factor [2]. Although the mechanisms implicated in this association are not well understood, alterations in the production of sex hormones and changes in secretion of bioactive peptides 
(adipokines) from adipose tissue have been linked as biological processes usually altered during cancer development $[3,4]$.

In contrast, hormonal dependency of $\mathrm{BC}$ has been extensively studied (estrogen receptor-ER and progesterone receptor- $\mathrm{PgR}$ ) and found to have significant prognostic and predictive value [5]. However, the significance of the androgen receptor (AR), is less well known. Important clinical associations between AR and BC have been reported [6,7], but the biological roles of androgens and the $\mathrm{AR}$ in the breast remain unclear, thereby limiting the therapeutic use of AR antagonists in the treatment of BC. Previous studies have suggested that obesity may influence $\mathrm{BC}$ risk through androgenic signaling [8,9]; however, evidence of relationship between these factors is inconclusive. Therefore, this review aims to describe the current knowledge on the clinical and biological associations between obesity and the AR signaling in BC. In particularly, we will discuss how the adipocyte-secreted factors (ASFs), adiponectin (ADPN) and leptin (LEP), could potentially interact with the AR signaling pathway to modify the behavior of normal and malignant mammary epithelial cells.

\section{Obesity and BC}

A body mass index (BMI) $\geq 30 \mathrm{Kg} / \mathrm{m}^{2}$ is commonly defined as obesity, which is considered an epidemic disease as $\sim 10 \%$ of the global population is obese [10], and the projections for some countries indicate that nearly one in two adults will be obese by 2030 [11]. Several studies have demonstrated a link between obesity and a higher risk of health complications, such as type 2 diabetes, heart disease, respiratory problems and cancer. For BC specifically, various systematic reviews and meta-analyses have reported that obese postmenopausal women have an approximately 1.1-1.7-fold increased risk of BC development, whereas an inverse association was observed in premenopausal women [12-16]. This was confirmed in almost 760,000 premenopausal women, showing that an increased BMI is associated with a reduced risk of premenopausal BC [17]. Additionally, obese postmenopausal BC patients have poor outcomes associated with adverse clinical characteristics, such as a larger tumor size or high-grade tumors [18-20]. Interestingly, most studies have shown that obesity tends to be correlated with ER negative (ER-) BC, even in premenopausal women [21-23]. However, others authors have reported an increased risk only for ER+ postmenopausal BC $[19,24,25]$.

The relationships among overweight/obesity and intrinsic BC molecular subtypes, have also been investigated. An analysis of 1676 postmenopausal BC women, revealed significant associations between being overweight (BMI $\geq 25$ ) and luminal $\mathrm{A}, \mathrm{B}$ and basallike intrinsic subtypes, and patients with basal-like BCs were more likely to be highly obese (BMI $\geq 35)$, compared with underweight/normal patients [26]. Moreover, whole-genome transcriptome analysis performed in triple negative BC (TNBC) patients, revealed specific gene signatures for both premenopausal and postmenopausal women, which enabled the differentiation between normal weight $\mathrm{BC}$ patients and overweight/obese patients [27].

\subsection{Biological Associations}

The pathogenesis of $\mathrm{BC}$ involves interactions between malignant cells and the mammary microenvironment, and therefore the tumor phenotype may be regulated by not only endocrine but also paracrine signals in the surrounding stromal tissue, which is mainly formed by adipocytes in BC. In this regard, the dysfunctional obese adipose tissue (hyperplasic and hypertrophic adipocytes) secretes high amounts of molecules and extracellular vesicles, which can target cells and promote cell-to-cell communication [28,29]. Elucidating these processes have allowed multiple mechanisms linking obesity with $\mathrm{BC}$ initiation and progression to be suggested. Among them, one indicates that hypertrophic adipocytes can trigger extracellular matrix $(\mathrm{ECM})$ remodeling through the secretion of matrix metalloproteinases and increased expression of collagen biogenesis enzymes [30]. The high degree of adipose tissue ECM plasticity also promotes angiogenesis and hypoxic states, which are 
crucial phenomena related to the release of pro-inflammatory cytokines (e.g NF- $\mathrm{B}$ and HIF-1 $\alpha$ ), cell growth and tumor survival in BC [31,32] (Figure 1).

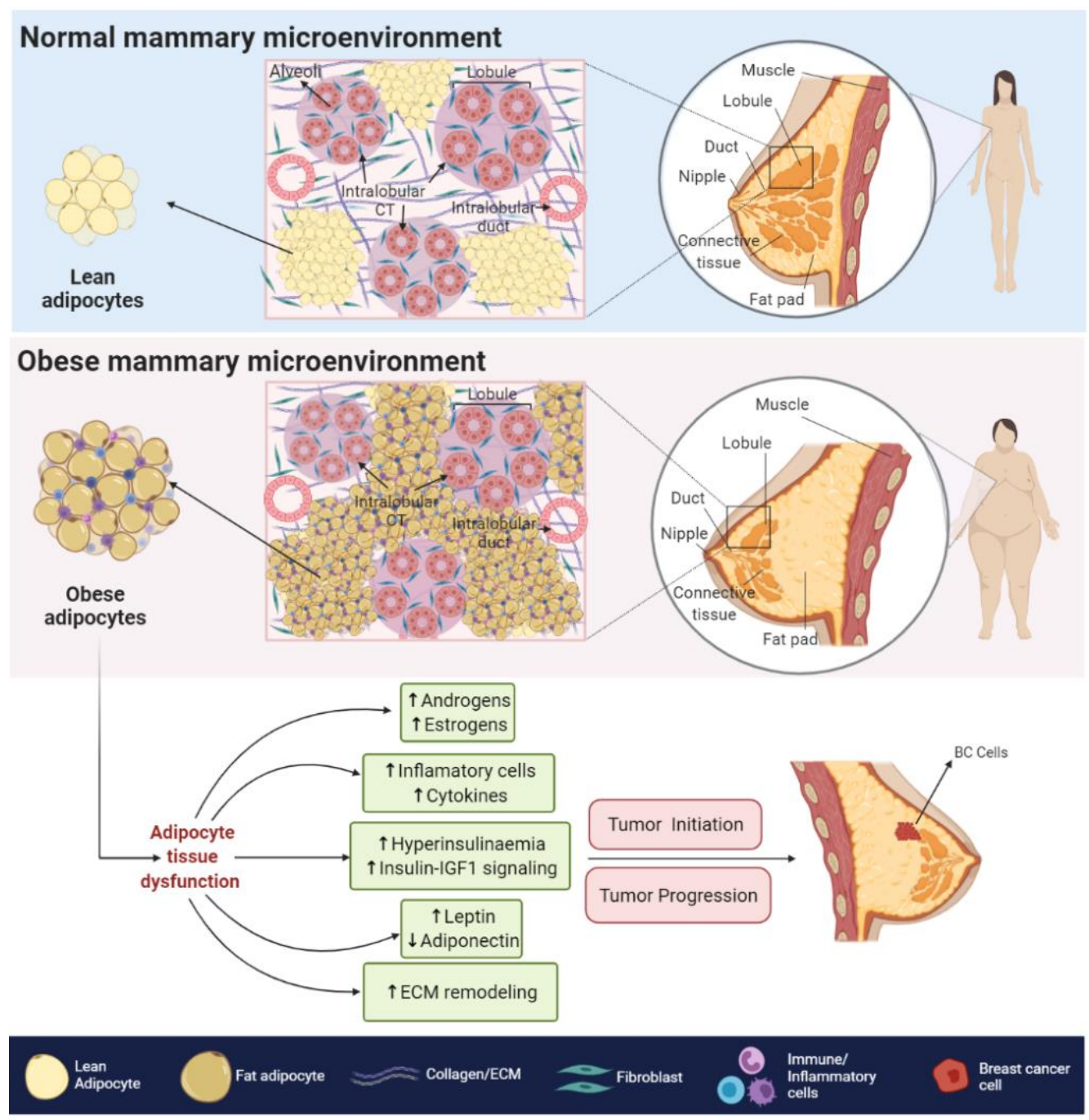

Figure 1. Normal vs. obese mammary microenvironment. Altered biological processes and production of ASFs are observed in obesity and are associated with BC development. CT—connective tissue; ECM-extracellular matrix.

The obesity-related hypoxic and inflammatory state is also associated with a decreased response to insulin and insulin-like growth factors (IGFs) signaling, leading to insulin resistance and hyperinsulinemia [33]. In BC cells, higher levels of insulin and IGFs signaling, promote the overstimulation of MAPK and PI3K/AKT pathways [29], both of which are related to increased cell proliferation, survival [34], angiogenesis [35], migration and epithelial to mesenchymal transition (EMT) [36]. Furthermore, the PI3K/AKT signaling regulates glucose metabolism, but cancer cells with impaired insulin function become glucose dependent and switch to relying on aerobic glycolysis for energy production rather than oxidative phosphorylation. This process, known as the Warburg effect, is notably increased in the obese microenvironment and supplies anabolic precursors to fuel the rapid growth and proliferation of BC cells [37]. Interestingly, these obesity-related mechanisms associated to BC, may be explained by dysfunctional secretion of adipokines, which include over 600 hormones and signaling molecules that work in an autocrine, paracrine or endocrine manner [38]. Among them, ADPN, LEP, Visfatin, Resistin, Vaspin, Cytokines (e.g., NFkB, $\mathrm{TNF} \alpha, \mathrm{IL6})$ and Progranulin (PGRN) have been related with cancer promotion $[39,40]$. For example, it has been reported that over-expression of PGNR mediates insulin resis- 
tance and obesity. Moreover, it stimulates migration, invasiveness and VEGF expression in BC cells. All of this may be explained by the PGRN ability of regulate PI3K/AKT and JAK-STAT signaling [41,42]. In addition, serum PGRN levels were associated with disease progression, therapy response and survival in patients with metastatic BC [43]. Nonetheless, ADPN and LEP will be extensively reviewed below, since they are currently the most important adipokines associated with cancer. In fact, increasing epidemiological and biological studies are investigating the correlation between their altered levels and functions with BC development (Figure 1).

\subsubsection{ADPN and BC}

ADPN is a monomeric glycoprotein able to trimerize forming a low molecular weight (LMW) isoform, then trimers can combine to form middle (MMW-hexamers) or high molecular weight (HMW until 18-mers) isoforms. Furthermore, ADPN may exist in a globular form, consisting only of the C-terminus domain [44]. ADPN isoforms are found at high concentrations in human serum $(5-30 \mu \mathrm{g} / \mathrm{mL})$ but are reduced in people with a $\mathrm{BMI}>25[45,46]$. Lower ADPN concentrations have been established as a risk factor for $\mathrm{BC}$ in pre- and postmenopausal women, which was recently confirmed by a meta-analysis of $\sim 30$ studies and more than 7000 cases [47] (Figure 1).

In vitro studies have demonstrated the anti-proliferative effects of ADPN on ER+ and ER - BC cells [48-50], but the mechanisms by which ADPN isoforms mediates protective roles against BC are not fully defined. ADPN binds to its classical receptors AdipoR1 and AdipoR2 and through recruitment of the adaptor protein APPL1 and the Ser/Thr kinase LKB1, it promotes the activation of the adenosine monophosphate-activated protein kinase (AMPK) [51] (Figure 2). AMPK is an energy sensor, that regulates protein and lipid metabolism by responding to alterations in energy supply and mediates the growth, survival and drug resistance of BC cells $[52,53]$. AMPK activation induces a strong inhibitory effect on the pro-tumorigenic MAPK and PI3K/AKT pathways [54]. Through AMPK signaling, ADPN further inhibits aromatase activity, which reduces E2 production, ER stimulation and BC cell proliferation [55]. Finally, ADPN may potentially activate PPAR $\alpha$, a nuclear receptor associated not only with fatty acid oxidation, reduced expression of inflammatory genes and suppression of $\mathrm{WNT} / \beta$-catenin signaling, but also related to BC cell growth and survival [56,57] (Figure 2).

Although ADPN is considered to reduce cellular viability, several studies have shown that ADPN may also increase the proliferation of ER+ cells and even negatively interfere with AMPK activation [58-62]. In fact, treatment of ER+ BC cells with ADPN levels similar to those observed in obese patients triggers a multiprotein complex (AdipoR1/APPL1/IGFIR/c-SRC) responsible for activating MAPK, which subsequently transactivates the ER to translocate to the nucleus and upregulate estrogen-dependent genes to promote cell growth [58-60] (Figure 2). In agreement with these results, pre-clinical studies using transgenic MMTVPyVmT (mouse mammary tumor virus-polyoma middle tumor-antigen) models of cancer, have displayed a pro-angiogenic contribution of ADPN to enhanced mammary tumor growth in vivo [63]. 


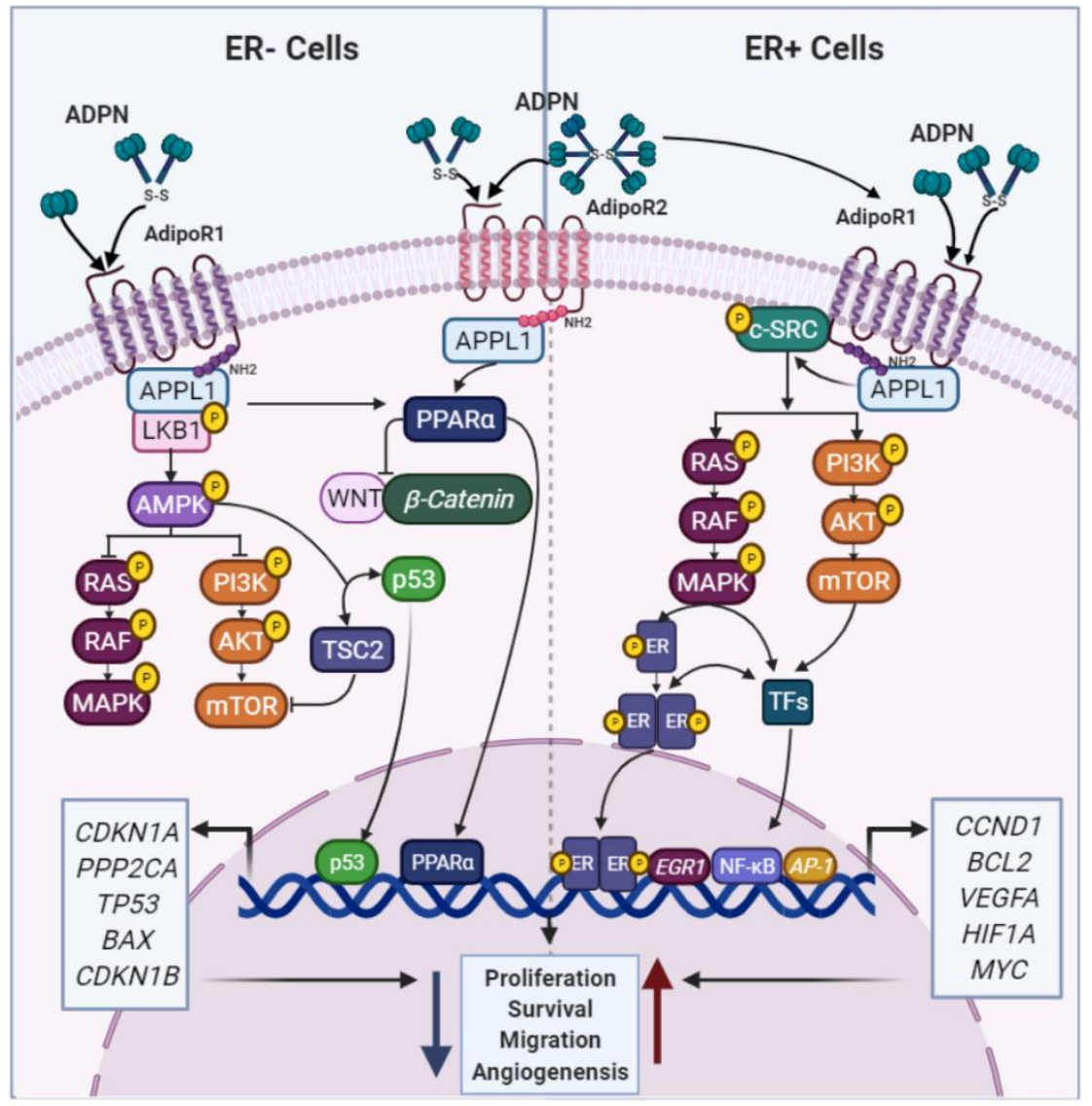

Figure 2. ADPN effects in BC cells. ADPN isoforms and their receptors regulate several signaling pathways to control BC cell behavior. However, it has been reported that ADPN can have anti- or prooncogenic effects depending on the ER status. PPAR $\alpha$ - peroxisome proliferator activated receptor alpha; TSC2-tuberous sclerosis 2; TFS-Transcription factors; EGR1-early growth response 1; CCND1-cyclin D1; BCL2 apoptosis regulator; VEGF-vascular endothelial growth factor; HIF1Ahypoxia inducible factor 1 subunit alpha; $C D K N 1 A$ — cyclin dependent kinase inhibitor $1 \mathrm{~A} ; P P P 2 C A-$ protein phosphatase 2 catalytic subunit alpha; TP53 - tumor protein p53; BAX-BCL2 associated X, apoptosis regulator; $C D K N 1 B$ — cyclin dependent kinase inhibitor $1 \mathrm{~B}$.

\subsubsection{LEP and BC}

LEP protein, encoded by the obese $(O b)$ gene, is expressed in several tissues but mainly in breast adipose tissue, possibly explaining why serum LEP levels are higher in women compared with men [64]. Although LEP can participate in a wide range of biological activities, it is primarily involved in regulating body weight by promoting diminuend caloric intake and reducing fat tissue storage through its appetite suppressant actions [65]. Nonetheless, LEP levels are highly increased in obese individuals and LEP is overexpressed in BC patients compared with healthy women [66,67] (Figure 1). In fact, most epidemiological reports and meta-analyses indicate that higher serum LEP levels are significantly associated with an augmented risk of BC development, mainly in postmenopausal patients $[68,69]$. Furthermore, LEP has been reported as a useful biomarker to differentiate BC patients according to its clinical characteristics (e.g., type, grade and stage) and also to classify tumors depending on their ER status, as ER- cases preferentially have higher LEP levels [70].

In contrast to ADPN, almost all studies have demonstrated that LEP exhibits procarcinogenic effects, which are mediated by activation of the obese receptor, a transmembrane protein with at least six alternatively spliced forms (Ob-Ra to Ob-Rf) [71-75]. These neoplastic effects might be explained by the relationship between the overexpression of both LEP and $\mathrm{Ob}-\mathrm{R}$ and the enhanced activation of classical signaling pathways. Specifi- 
cally, it has been demonstrated that LEP stimulate BC cell cycle progression and survival by upregulating MYC, CD1, BCL2 and TERT expression via JAK2/STAT3 activation [73,76]. LEP also promote the expression of the well-recognized oncogenes JUN and FOS by activating ERK1/2, p38 and JNK, which are typical members of the MAPK signaling pathway $[77,78]$. In ER+ BC, LEP may stimulates aromatase expression to increase E2 synthesis and further, induce direct functional activation of the ER through STAT3 and ERK-mediated phosphorylation [79]. Moreover, through STAT3 and PI3K/AKT pathways, LEP can upregulate the expression of key markers of EMT, angiogenesis and metastasis (e.g., E-cadherin, Vimentin, VEGF, PKM2 and ACAT2) [30,36,80-83], in both ER+ and ERBC cells (Figure 3).

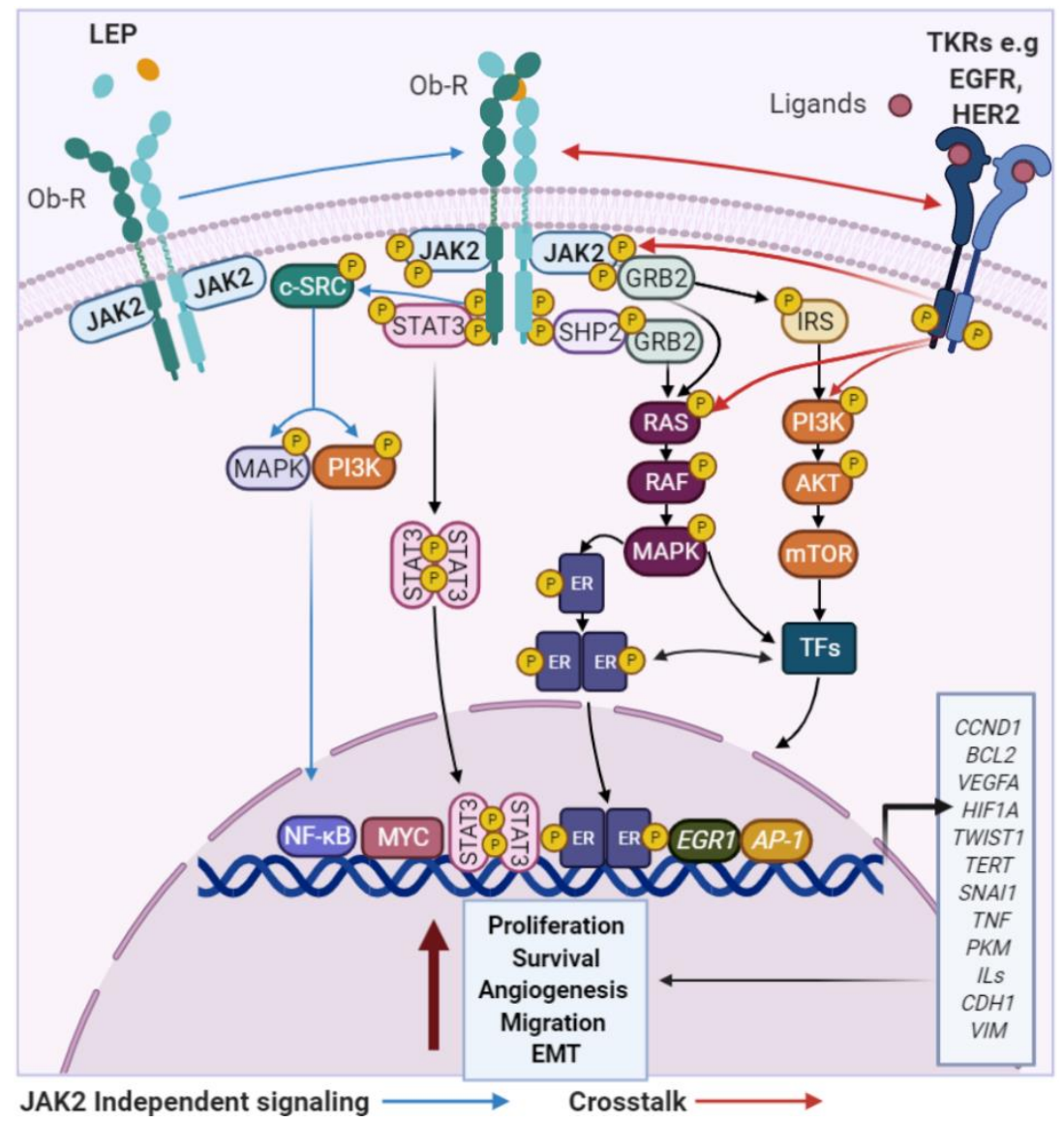

Figure 3. LEP effects in BC cells. LEP and Ob-Rs activate classical signaling pathways to regulate the expression of genes related to increased BC development independently of the ER status. TKRs_tyrosine kinase receptors; EGFR—epidermal growth factor receptor; JAK2 - janus kinase 2; STAT3 - signal transducer and activator of transcription 3; GRB2-growth factor receptor bound protein 2; SHP2 - protein tyrosine phosphatase non-receptor type 11; IRS2-insulin receptor substrate 2; TWISTS1 - twist family bHLH transcription factor 1; TERT - telomerase reverse transcriptase; SNAI1-snail family transcriptional repressor 1; TNF-tumor necrosis factor; PKM-pyruvate kinase M1 2; ILs—Interleukins; CDH1—E-cadherin; VIM—vimentin.

Finally, LEP is considered one of the most important obesity-associated proinflammatory adipokines. It has been reported that higher LEP levels may stimulate NF- $\kappa B$ to increase the expression of pivotal inflammatory mediators such as TNF, IL-1b, and COX-2 [84]. This is associated with enhanced recruitment of infiltrating immune cells (e.g., macrophages) to the mammary microenvironment, thus promoting $\mathrm{BC}$ progression [32]. All of the pro-carcinogenic effects attributed to LEP have been confirmed using inhibition assays inhibiting or blocking it (e.g., RNA interference or monoclonal antibod- 
ies) which abolish LEP-induced oncogenic effects and BC cell growth in both in vivo and in vitro models $[36,85]$.

\section{AR Signaling and BC}

Approximately $75 \%$ of all BCs are ER+. Therefore, most of BC research has focus on identifying the targets and roles of this steroid receptor and its main ligand E2. However, an extensive amount of evidence suggests that estrogens are not the only steroid molecules related to $\mathrm{BC}$ [86-88], and it has even been shown that hormonally regulated transcription is remarkably maintained in $B C$ subsets with low levels of ER expression or in patients with ER- BC tumors [89,90]. These insights indicate the involvement in BC of additional steroid hormones and its receptors, such as the AR, which is widely expressed in normal breast epithelial cells.

Androgenic hormones are the major circulating sex hormones in both sexes [91]. In females, the ovaries and the adrenal cortex are the main sources of dehydroepiandrosterone (DHEA), dehydroepiandrosterone-sulfate (DHEA-S) and androstenedione (4-dione), which are the major sex steroid precursors of the most potent active metabolites targeting AR (testosterone (T) and $5 \alpha$-dihydrotestosterone (DHT)) [92]. Several clinical data points to androgens as circulating molecules associated with an increased risk of $\mathrm{BC}$ development in pre- and postmenopausal women [86,93-95]. However, a recent study revealed that independently of menopausal status, $\mathrm{T}$ and DHEA-S serum levels are not useful to predict BC prognosis [96].

In contrast, $80-90 \%$ of ER+ tumors are also AR-positive (AR+) and associated with favorable prognoses (e.g., longer relapse-free survival, lower tumor grade, and smaller tumor size) [97,98], which has been confirmed in several meta-analyses [99-101]. Regarding ER- BC, up to $31 \%$ of them are reported to be AR+ [102] and although some experimental studies and meta-analyses show that AR positivity is associated with improved outcomes $[101,103,104]$, other studies have reported contradictory results $[7,105,106]$. Despite the above, recent evidence have shown that AR pathway activity is increased in all BC subtypes compared with normal breast tissue [107], making this signaling pathway an interesting target in the study of mammary tumor development and progression.

\subsection{Biological Associations}

AR signaling it is recognized as a master regulator of gene programs associated with a wide variety of biological processes including reproduction, differentiation, cell proliferation, apoptosis, inflammation, metabolism and homeostasis [108]. Androgens and AR employ two main mechanisms in order to exert their functions: (i) dimerization and nuclear translocation of the ligand-stimulated AR that promotes AR-DNA interactions on androgen response elements (AREs) of its target genes [109], and (ii) a non-genomic signaling/action, where androgens can directly activate GPCRs or even regulate the binding of ligand-stimulated AR to cytoplasmic and membrane-bound proteins. Both processes result in the consequent activation of second messengers (e.g., c-SRC) that may induce classical signal transduction cascades [110] (Figure 4).

Different reports have shown that DHEA, DHEA-S, 4-dione and their derivates, can influence the proliferative capacity of breast epithelial cells [86,111]. Furthermore, endogenous aromatization of $\mathrm{T}$ (to produce E2) or DHT treatment stimulates the growth of ER+ and ER- BC cell lines [112-114]. The same pro-tumorigenic effect was also observed for 4-dione and androstenediol in different BC models [88]. However, some authors reported that androgens, such as 4-dione, DHT and even T, inhibit the proliferation of both $\mathrm{ER}+$ and ER- BC cells $[115,116]$. Of note, by accurately quantifying steroid hormones, Moon et al. confirmed that the androgens mentioned above are most abundant in BC tumors but show a large variation among patients [117]. This finding, together with the fact that the molecular mechanisms by which androgens control biological processes are not completely known and that the age of menarche and menopause is variable among 
patients [118], explain the contrasting data reported and more importantly highlight the need for additional basic and functional research to clarify this topic.

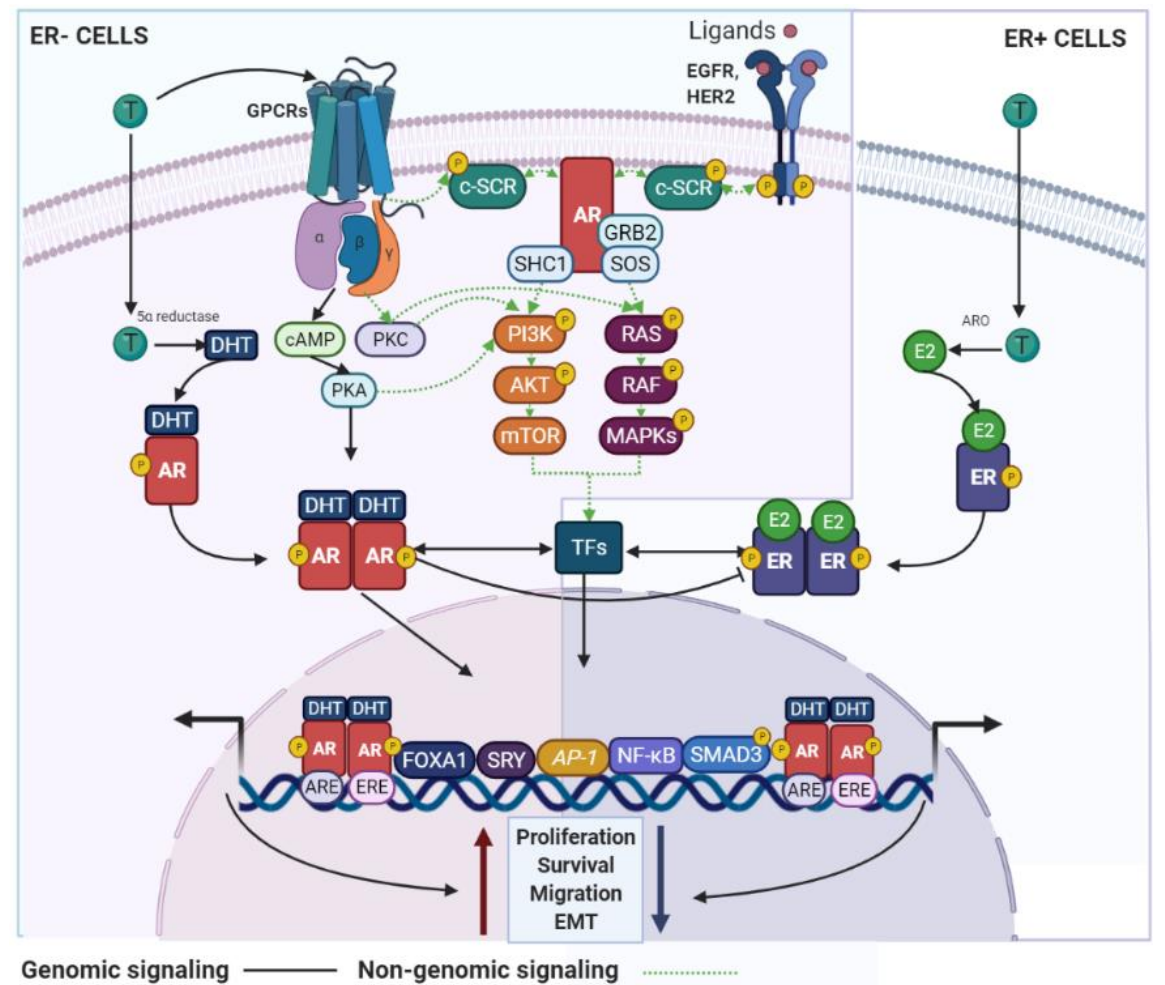

Figure 4. AR signaling in BC cells. AR use genomic and non-genomic mechanisms that can regulate BC development. These signaling pathways are associated with inhibitory or stimulatory effects on the BC cell growth and are dependent of the ER status. GPCR-G protein-coupled receptors; SHC1SHC adaptor protein 1; SOS—SOS Ras/Rac guanine nucleotide exchange factor; ARO-aromatase.

\subsubsection{The AR in ER+ BC}

Many in vitro studies have shown that AR signaling consistently inhibits the basal and estrogen-induced proliferation and survival of MCF-7, T47D and ZR-75-1 cell lines (classical models of luminal BC) $[115,116,119]$. Its potent anti-proliferative effects were confirmed in MCF-7 cells transfected to overexpress the wild-type or a constitutively active form of the AR [120]. These cells exhibited downregulated expression of CCND1 and PTEN and activation of CDKN1A, TP53 and BRCA1, which are well-recognized oncogenes and tumor-suppressor genes, respectively [121-123]. At the cellular level, the AR and ER colocalize, providing evidence of signal crosstalk between them [120]. In support of this idea, competition studies for co-regulatory molecules, have demonstrated that in the presence of low AR levels, steroid receptor co-activators (e.g., ARA70) predominantly bind to ER, thereby increasing ER-induced proliferation. Following AR overexpression, coactivators preferentially interact with the AR to antagonize ER signaling [124]. Furthermore, a study using ZR-75-1 cells, displayed reciprocal interference between DHT and E2-induced transcriptional programs, suggesting that AR may antagonize ER signaling by competing with ER for binding to estrogen response elements (EREs) [125] (Figure 4). Inhibitory effects of the AR on ER activity have also been observed through E2 downregulation as AR actions are involved in aromatase transcription decrease [126].

The effects of AR signaling on cell growth however appear to be highly variable in MCF7 cells. Some authors have demonstrated that the AR can maintain a proliferative cell status [110,127-130] and even suggest that high AR expression may contribute to endocrinetherapy resistance (to both tamoxifen and aromatase inhibitors-AI) [131-134]. This appears to be explained by activation of the AR and ER non-genomic mechanisms that promote 
the activation of signaling cascades associated with proliferation and hormone therapy resistance $[129,130]$ (Figure 4). In line with the positive effect of the AR on cell growth, it has been demonstrated that high AR and low ER protein expression levels (AR/ER ratio $\geq 2$ ) are associated with unfavorable clinical features, tamoxifen resistance and poor survival in ER+ BCs $[135,136]$. Additionally, ER+ tumors with increased AR expression levels, are characterized by enhanced expression of cell proliferation markers and preferentially classified as luminal B or HER2-enriched tumors [90], which are recognized as more aggressive molecular subtypes.

As AR signaling have shown to inhibits estrogen-induced proliferation and survival of $\mathrm{ER}+\mathrm{BC}$ cells, natural and synthetic steroidal androgens were used as therapeutic approach, however they were discontinued for induce serious side effects [137]. Furthermore, the AR agonist enobosarm, a selective AR modulator (SARM), have been proposed to reduce tumor growth in preclinical studies [138], but a clinical trial using different doses of it did not confirm previous results, when administered in postmenopausal ER+ BC patients (NCT02463032). On the other hand, according to the positive effects of AR on ER+ cell proliferation, preclinical studies have confirmed that antiandrogens (i.e., bicalutamide and enzalutamide) inhibit ER+ BC growth by abrogating AR nuclear translocation. However, a clinical trial showed that bicalutamide in combination with AI did not have clinical benefit rates (CBR) in patients with ER+ BC and AI resistance [139]. In contrast, recent results from an additional clinical trial, indicate that in $\mathrm{ER}+\mathrm{BC}$ s a subset of women with both high levels of $A R$ mRNA and low levels of ESR1 (ER) mRNA, may benefit from enzalutamide in combination with the AI exemestane [140]. This confirm our previous reports which indicate that high AR levels respect to ER levels may help to identify and treat a specific subgroup of ER+ patients (luminal BC) having tumors with unfavorable clinical and molecular characteristics [90,136].

The above results support the idea that the AR and androgens (DHEA, 4-dione, T, DHT), may play a proliferative role in ER+ tumors. However, combining the data from in vivo and in vitro studies, it appears that a fine-tuning regulation of androgens and estrogens levels, as well as of their receptors, is essential to keep balanced its functions in mammary tissue. Accordingly, two insights could explain the contradictory effects of AR positivity on ER+ BCs: (i) the AR appears to have context-dependent roles as it shifts from an anti-proliferative stimulus to a pro-proliferative one, depending on the high and low expression levels of ER, respectively, and (ii) although AR positivity likely reflects well-differentiated BCs and is thus associated with a good prognosis, the biological effects of AR signaling, when over-stimulated by genomic or non-genomic mechanisms, may confers worse outcomes in BC, which has been recently suggested [141].

\subsection{2. $\mathrm{AR}$ in $\mathrm{ER}-\mathrm{BC}$}

In line with the effects of AR in tumors with low ER levels, in vitro studies have shown that the stimulation of the AR signaling can promotes the proliferation of $\mathrm{ER}-\mathrm{BC}$ cell lines with high (MDA-MB453) or low AR levels (MDA-MB231, MFM-223) [89,142,143]. This was confirmed by siRNA mediated AR knockdown and treatment with anti-androgenic drugs (enzalutamide and bicalutamide), which significantly inhibited the proliferation of MDA-MB453 and other TNBC cells [143,144]. These experiments further showed increased apoptosis and changes in the morphology of ER- cells, which were related to decreased rates of migration and invasion [145] (Figure 4).

Androgen-induced growth of MDA-MB453 cells has been shown to be associated with activation of the WNT/ $\beta$-catenin and HER2 pathways [135]. These signaling pathways have the ability of stimulate MAPK and PI3K cascades, leading to the upregulation of mitogenic signals from AR. Additionally, it has been reported that MDA-MB453 cells appear to have a high frequency of PI3K mutations [146], and an association between AR, EGFR and ERK1/2 activity has also been identified in TNBC, as treatment with inhibitors of these molecules decreased the amount of $\mathrm{AR}$ and had an additive anti-proliferative effect [147]. Besides, in MDA-MB453 cells, the AR can bind to the promoters of genes 
related to mitogenic effects, that in MCF7 cells are normally occupied by ER $[144,148]$ (Figure 4).

Regarding biological behaviors, extensive molecular profiling and clustering studies have identified great heterogeneity within ER - tumors (basal-like BC subtypes) [149]. Among them, the luminal AR (LAR) subtype, is associated with a transcriptomic profile enriched for AR expression signaling pathways and for having a luminal-like gene profile $[89,143,150,151]$. LAR tumors are characterized to be highly aggressive [152,153], which has emphasized the need for clarifying the role of AR in BC and promoted the development of several $\mathrm{AR}$ antagonists that are currently being tested in multiple clinical trials alone or in combination with other treatment strategies for ER- BC, which have been comprehensively reviewed by other authors [108,154-156]. To note, a phase II clinical trial comprising 424 TNBC patients, showed bicalutamide provide good results and have a considerable CBR at 6 months (19\%) [157]. Another single-agent phase II clinical trial assessed the effectiveness of enzalutamide in 75 patients with AR+ TNBC, showing that CBR was $28 \%$ at 24 weeks [158]. Particularly, LAR subtype cells frequently carry PI3K mutations $[146,159]$. Thus, in a phase IB/II clinical trial, Lehmann et al., demonstrated that the combination of enzalutamide with taselisib, a PI3K inhibitor, significantly increased the CBR of TNBC patients $(35.7 \%)$, but among them, LAR subtype patients trended towards better response compared to non-LAR $(75.0 \%$ vs. $12.5 \%, p=0.06)$ [160]. In general, few side effects have been reported from all these strategies, indicating its potential use for women with TNBC.

\section{Obesity, AR Signaling and BC}

As mentioned above, the ovaries and the adrenal cortex are the main sources of androgens, but in postmenopausal women these sex steroids are mainly synthesized by adipose tissue $[161,162]$. This suggests that obesity may contribute to a hyperandrogenic state, and as the breast is largely constituted by adipose tissue, the increased local androgen production should not be ignored in $\mathrm{BC}$ research. In fact, a pioneering study reported higher DHEA concentrations in the mammary adipose tissue of obese subjects, even in the adjacent adipose tissue of malignant BC compared with benign tumors [163]. Moreover, overweight BC patients with high T levels, clearly have worse prognoses [164], and a combined harmful effect of high serum $\mathrm{T}$ concentrations and a non-healthy dietary pattern on BC risk has been reported [165]. In agreement with this, the Nurses' Health Study showed that weight gain and higher BMIs $(>25)$ are associated with an increased risk of developing AR+ tumors in postmenopausal women [104].

Biologically, the increased androgen synthesis induced by obesity may favors the growth of ER+ cells due to T aromatization and augmented E2 production. However, it must also be assumed that the proliferative stimulus may be enhanced by the itself elevation of androgens and their interaction with AR. In line with this insight, a recent study demonstrated that in a preclinical model of obesity, AR transcriptional activity was increased and promoted ER+ BC progression in environments with low E2 availability (i.e., in postmenopausal cases). Thus, in models treated with enzalutamide (anti-androgenic drug), AR inhibition prevented obesity-associated tumor progression by suppressing the proliferation and survival of BC cells [166]. Hence, high AR expression in obesity could play a positive role in $\mathrm{BC}$ progression when ER expression levels are low. Consistent with this idea, patients with basal-like BCs (ER- or low expression) are more likely to be obese, compared with underweight/normal patients [26], and tumors with high AR and low ER expression levels (AR/ER ratio $\geq 2$ ) are associated with more aggressive $B C$ molecular subtypes $[90,136]$. Together these results allow suggest that in obesity ER expression may decrease, opening the possibility that the increased androgen synthesis observed in this environment, results in specific overstimulation of AR signaling to maintain active pathways related to tumor progression and aggressiveness. 


\subsection{Adipokines and the AR: Potential Links in BC}

Although it has been reported that postmenopausal obese women have elevated circulating or mammary adipose tissue androgens levels compared with lean women, some studies have found inconsistent results [166]. Therefore, AR signaling modulation cannot be entirely explained by the discrepancy in androgens levels between obese and lean individuals. Among other factors regulating AR signaling, the adipokine IL-6 has been shown to sensitize ER+ and ER- BC cells to T, as the expression of the $A R$ and its target gene $F K B P 5$, were significantly increased. Bioinformatic analyses further demonstrated that $A R$ and $F K B P 5$ expression were higher in ER+ BC cases with increased IL-6 levels [166]. To the best of our knowledge, direct associations between the AR signaling pathway and important adipokines, such as ADPN and LEP, have not been yet reported in BC cells, but similarly to IL-6, their action mechanisms lead us to believe that functional interaction among them and AR, cannot be ruled out.

\subsubsection{ADPN and AR}

Most studies indicate that $\mathrm{AR}$ signaling plays a positive role in $\mathrm{ER}+\mathrm{BC}$ prognoses by blocking ER function. In this context, ADPN has been reported to prevent androgens aromatization [55], which involves increased levels of androgenic hormones in mammary tissue, AR overstimulation and increased inhibition of the ER signaling. Therefore, the decreased levels of ADPN, observed in obesity and cancer, may favor ER-driven BC progression by reducing the activation of the AR signaling. In ER - tumors, in which AR activation is associated with sustained growth, low ADPN levels may decrease the inhibition of the AR signaling, thereby maintaining the proliferative status of this $\mathrm{BC}$ subtype (Figure 5).

ADPN can activate multiple intracellular signaling pathways. Through AMPKindependent signaling, ADPN promotes interactions with TKRs, such as the IR, which may increase PI3K and MAPK signaling in both ER+ and ER- BCs [59,60]. These signaling pathways may be enhanced by crosstalk between TKRs and the membrane-bound AR form, which has been reported to activate these classical pathways $[58,61,167]$. Furthermore, several ligand-independent phosphorylation sites in the AR protein have been identified to act as regulatory hot-spots capable of sensing cellular signaling and guiding biological responses in BC cells $[129,130]$. In fact, c-SRC, AKT, ERK1/2 and other MAPK-pathway associated factors, reported to be regulated by ADPN [168], can promote the ligand-independent activation of AR via phosphorylation at its N-terminal and hinge region domains [167]. All of these AR-dependent non-genomic mechanisms may serve as potential links to ADPN in BC (Figure 5).

It cannot be excluded that ADPN functions in BC cells, might also be performed through the direct regulation of $A R$ gene expression. In fact, several pioneer and general transcription factors (e.g., AP-1, CREB, FOXA1 and SP1) target the $A R$ promoter and can be regulated by pathways stimulated by ADPN [169]. It has been reported that some adipokines, can suppress androgen sensitivity and the proliferation of androgen-dependent LNCaP cells (prostate cancer) through AR downregulation [170]. A similar behavior in BC, by decreased levels of ADPN in obesity, would support the inhibitory effect of ADPN in ER - or low ER expression postmenopausal cases, in which AR signaling plays a clearer role as a tumor promoter. In this cellular environment, opposite effects on $A R$ expression might induce $\mathrm{BC}$ cell growth, consistent with the reported tumorigenic actions of ADPN [58-60]. In an $\mathrm{ER}+\mathrm{BC}$ context, the downregulation of $A R$ expression by decreased levels of ADPN would promote tumor growth because the AR would not be enabled to inhibit ER signaling (Figure 5).

Accordingly, ADPN has the potential to transactivate the $A R$, which has been reported for the ER [59,60]. However, it must be considered that the specific effects of ADPN effects on AR signaling may vary depending on the changes in ADPN levels, as observed in both obesity and BC. 


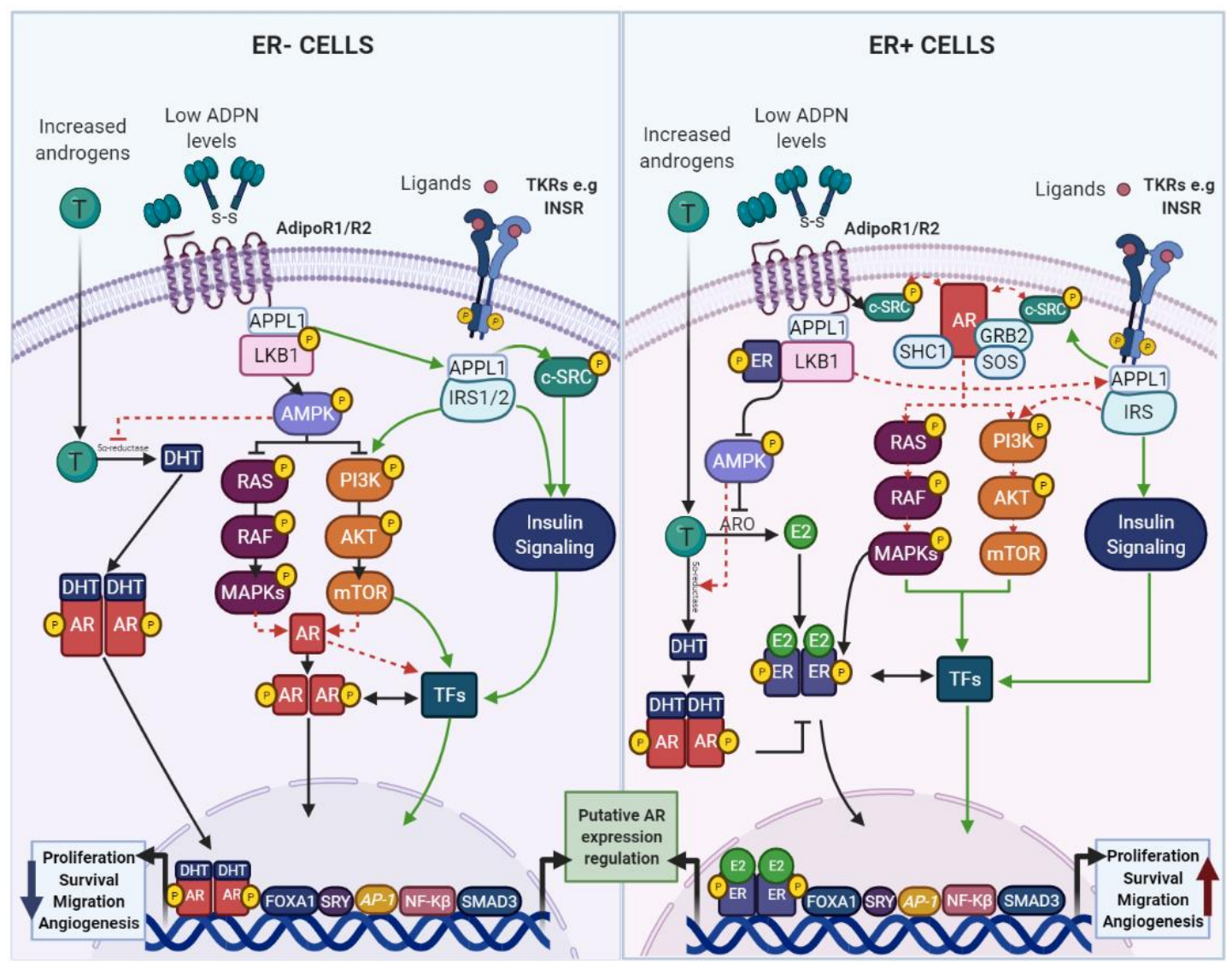

ADPN and AR

Potential crosstalks

ADPN AMPK-Independent signaling

Figure 5. Potential links between ADPN and AR signaling. ADPN and the AR activate common signaling pathways and the crosstalk between them may be involved in regulating BC development, that is dependent on the ER status. INSR-insulin receptor; SRY—sex determining region $\mathrm{Y}$.

\subsubsection{LEP and AR}

Although it has been reported that androgens can modulate LEP expression in adipocytes [171], the effects of LEP on AR signaling in normal and malignant mammary epithelial cells have not been described. However, several studies have confirmed that increased levels of LEP and AR are found in obese-postmenopausal BC cases $[32,68,70,163,166]$ and both have been identified as oncogenic factors that use similar signaling pathways. Therefore, a functional crosstalk among them cannot be excluded.

Upon LEP binding, the Ob-Rs trigger downstream cascades in two different ways, (i) via phosphorylation of JAK/STATs or (ii) by activation of several adaptors or membraneassociated proteins (e.g., GRB2, SOS, SHP2 and c-SRC) [172]; Both mechanisms are independently identified as elements that targets and promote ligand-independent activation of the membrane-bound AR form [167,173,174] (Figure 6). In support of this insight, previous data have shown that STAT3 activation enhances its interaction with the AR N-terminal domain in prostate cancer cells stimulated with the adipokine IL-6 [175-178]. In ER - or low ER expression BC cells, if a similar JAK/STAT-mediated interaction between the AR and LEP occurs, presuppose an activation of the AR pro-tumorigenic signaling (non-genomic effects), as well as, its nuclear translocation to further enhance cell growth (genomic effects). Conversely, considering the anti-tumorigenic effect of the AR in ER+ BCs, these interactions would involve inhibition of AR signaling to promote the oncogenic roles of the ER, furthering agreeing with the ability of LEP to induce increased aromatase expression $[78,79,179]$. Additionally, the AR has been shown to phosphorylate HER2, and interactions between 
Ob-R and HER2 have also been reported, both leading to the subsequent activation of JAK/STATs, PI3K/AKT and MAPK signaling [81,180]. This crosstalk could be specifically mediated by the membrane-bound AR form as all of these factors can activate adaptor proteins like c-SRC. Therefore, the activation of non-genomic AR mechanisms by either Ob-R or HER2 would promote the oncogenic signaling of each other (Figure 6).

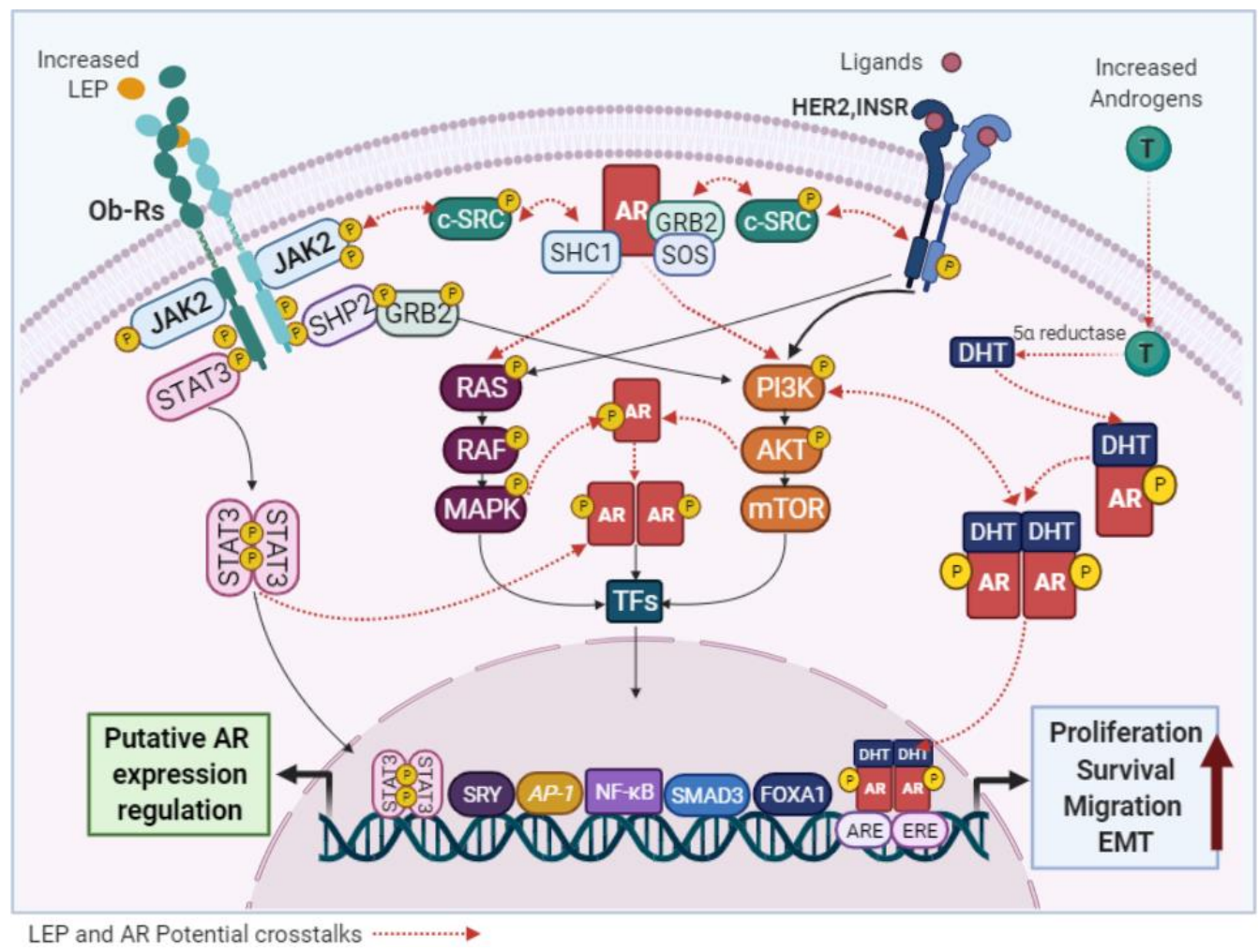

Figure 6. Potential links between LEP and AR signaling. LEP and the AR activate common signaling pathways and the crosstalk between them, may be responsible for the pro-stimulatory effects of LEP observed in BC cells.

Of note, STAT-family members are transcription factors itself that bind to a gammaactivated sequence or an interferon-stimulated response element, and according to the Signaling Pathways Project web knowledge base, these elements have been identified in the AR gene promoter region [181,182]. This suggests that the LEP-mediated activation of STAT family members could directly regulate $A R$ gene expression, similar to IL-6 [166]. Indeed, a recent study reported that $A R$ expression was downregulated in LNCaP cells cultured in the presence of high LEP concentration [183]. In luminal BC cells, the observation of a similar effect on $A R$ gene expression, has led to the hypothesis that high LEP levels might potentiates the oncogenic effects of the ER by reducing AR levels and its inhibitory action on the ER. In contrast, opposite effects on AR expression could be observed in ER- or low ER expression cells, which would be consistent with the confirmed pro-tumorigenic role of both, LEP and the AR, in basal-like BC subtypes [74,103] (Figure 6).

\section{Concluding Remarks and Future Perspectives}

$\mathrm{BC}$ is a heterogenous disease, and its development and progression depends on several risk factors. Of these, obesity is an increasing health challenge that certainly modifies the behavior of normal mammary tissue by dysfunctional secretion of molecules from hyperplasic and hypertrophic adipocytes. Therefore, in addition to endocrine signals originating from distal adipose tissues, the direct effects of paracrine signals from the local adipose tissue in breast microenvironment should be a primary research focus. Among the ASFs, altered ADPN and LEP levels have been shown to be independently associated with $B C$ development. LEP functions are clearly pro-tumorigenic, whereas ADPN actions 
appear to be ER-status dependent. In this regard, it will be challenging to determine how the opposing actions of ADPN promote growth in ER+ cells but inhibit ER-cells. Other molecules produced by adipose tissue include androgens, which are steroid hormones with altered levels in obese and BC cases. Similar to ADPN, AR signaling has been shown to have ER context-dependent roles. Specifically, AR activation promotes ER- BC cell proliferation, but inhibition of the E2/ER-stimulated growth. Regardless of the specific end-effect of ADPT, LEP, or androgen/AR on BC cells, it has been clearly reported that their actions are mainly modulated by similar intracellular signal transduction pathways. These similarities suggest that crosstalk between adipokines and AR signaling can occur, and that there is a high probability that these interactions are responsible for modifying the behavior of normal and malignant mammary epithelial cells, especially in obesity.

To better understand how modified levels of ADPT, LEP, and AR influences BC development and progression, improved in vitro (e.g., co-culture experiments) and in vivo (e.g., tissues or cell lines xenograft specimens) experimental obesity models are required to study their interactions. These approaches will allow the evaluation of not only the degree to which the adipokines and the AR promote activation or inactivation of each other, but also whether their coordinated actions can modulate the biological processes that they are involved in. Because the epidemiological data are inconsistent, regarding the association of obesity with hormone receptor expression, menopausal status and BC subtypes, it will be interesting to clarify the relationship between lifestyles and clinical associations. To address this topic, further epidemiological studies with a larger number of included patients are needed. Additionally, the assessment of potential correlations among adipokines with androgen levels or AR status will be useful to establish their influence on BC prognosis.

Clearly, obesity is a biological variable that merits consideration regarding the therapeutic strategies used to manage BC. Accordingly, and because of the modifiable nature of obesity, the most recommendable approach must be to promote lifestyle changes (in preand postmenopausal women) to achieve a healthy weight to prevent cancer development and even improve $B C$ treatment efficacy. In line with our literature review, it is logical to assume that drugs targeting ADPN, LEP and even adipokines less studied as PGRN, require a deeper evaluation on their use in $\mathrm{BC}$ management. However, regarding $\mathrm{AR}$, clinical trial results indicate that antiandrogen therapies may be effective and needed for AR+ TNBC patients, especially for LAR subtypes or even non-LAR with AR-weak positivity. Furthermore, although AR inhibition seems not to be widely effective in ER+ patients, focus need to be put in the identification of luminal tumors where AR levels are higher respect to ER levels. Preclinical and clinical research suggest that these tumors, as well as AR+ HER2-Enriched BC subtypes, are more dependent on androgen signaling. Therefore, additional studies using antiandrogen therapies, alone or in combination with other strategies, should be considered as an important medicinal target, that in the future, will allow to obtain significant clinical benefits for patients with different BC subtypes.

The knowledge of how ADPN and LEP can interact with the AR signaling pathway in breast epithelial cells may prospectively guide the development of new therapeutic approaches aimed at potentiating the inhibitory actions of the antiandrogen therapies in BC. Nevertheless, the use of drugs targeting ADPN and the AR as potential therapeutic tools, will have to be carefully assessed and separately studied according to the ER status, because of the contradictory effects reported of they in each BC tumor subtype.

Author Contributions: N.R., V.E.V. and M.R.-L. wrote the original draft and designed the figures. All authors have read and agreed to the published version of the manuscript.

Funding: This work was supported by Universidad del Rosario.

Acknowledgments: The authors would like to acknowledge support for figures preparation to Erika Viviana Perez.

Conflicts of Interest: The authors declare no conflict of interest. 


\section{References}

1. Ferlay, J.; Colombet, M.; Soerjomataram, I.; Mathers, C.; Parkin, D.M.; Piñeros, M.; Znaor, A.; Bray, A.F. Estimating the Global Cancer Incidence and Mortality in 2018: GLOBOCAN Sources and Methods. Int. J. Cancer 2018, 144, 1941-1953. [CrossRef] [PubMed]

2. Lauby-Secretan, B.; Scoccianti, C.; Loomis, D.; Grosse, Y.; Bianchini, F.; Straif, K. Body Fatness and Cancer-Viewpoint of the IARC Working Group. N. Engl. J. Med. 2016, 375, 5. [CrossRef] [PubMed]

3. Lapeire, L.; Denys, H.; Cocquyt, V.; De Wever, O. When fat becomes an ally of the enemy: Adipose tissue as collaborator in human breast cancer. Horm. Mol. Biol. Clin. Investig. 2015, 23, 21-38. [CrossRef]

4. Park, J.; Euhus, D.M.; Scherer, P.E. Paracrine and endocrine effects of adipose tissue on cancer development and progression. Endocr. Rev. 2011, 32, 550-570. [CrossRef] [PubMed]

5. Early Breast Cancer Trialists' Collaborative Group; Davies, C.; Godwin, J.; Gray, R.; Clarke, M.; Cutter, D.; Darby, S.; McGale, P.; Pan, H.C.; Taylor, C.; et al. Relevance of breast cancer hormone receptors and other factors to the efficacy of adjuvant tamoxifen: Patient-level meta-analysis of randomised trials. Lancet 2011, 378, 771-784. [CrossRef] [PubMed]

6. Amaral, C.; Augusto, T.V.; Almada, M.; Cunha, S.C.; Correia-da-Silva, G.; Teixeira, N. The potential clinical benefit of targeting androgen receptor (AR) in estrogen-receptor positive breast cancer cells treated with Exemestane. Biochim. Biophys. Acta Mol. Basis. Dis. 2020, 1866, 165661. [CrossRef] [PubMed]

7. Xu, M.; Yuan, Y.; Yan, P.; Jiang, J.; Ma, P.; Niu, X.; Ma, S.; Cai, H.; Yang, K. Prognostic Significance of Androgen Receptor Expression in Triple Negative Breast Cancer: A Systematic Review and Meta-Analysis. Clin. Breast Cancer 2020, 20, e385-e396. [CrossRef]

8. Pasquali, R. Obesity and androgens: Facts and perspectives. Fertil. Steril. 2006, 85, 1319-1340. [CrossRef]

9. Schapira, D.V.; Kumar, N.B.; GH, L. Obesity, body fat distribution, and sex hormones in breast cancer patients. Cancer 1991, 67, 4 . [CrossRef]

10. NCD Risk Factor Collaboration. Worldwide trends in body-mass index, underweight, overweight, and obesity from 1975 to 2016 : A pooled analysis of 2416 population-based measurement studies in 128.9 million children, adolescents, and adults. Lancet 2017, 390, 2627-2642. [CrossRef]

11. Ward, Z.J.; Bleich, S.N.; Cradock, A.L.; Barrett, J.L.; Giles, C.M.; Flax, C.; Long, M.W.; Gortmaker, S.L.; Projected, U.S. State-Level Prevalence of Adult Obesity and Severe Obesity. N. Engl. J. Med. 2019, 381, 2440-2450. [CrossRef]

12. Choi, E.K.; Park, H.B.; Lee, K.H.; Park, J.H.; Eisenhut, M.; van der Vliet, H.J.; Kim, G.; Shin, J.I. Body mass index and 20 specific cancers: Re-analyses of dose-response meta-analyses of observational studies. Ann. Oncol. 2018, 29, 749-757. [CrossRef]

13. Fang, X.; Wei, J.; He, X.; Lian, J.; Han, D.; An, P.; Zhou, T.; Liu, S.; Wang, F.; Min, J. Quantitative association between body mass index and the risk of cancer: A global Meta-analysis of prospective cohort studies. Int. J. Cancer 2018, 143, 1595-1603. [CrossRef]

14. Freisling, H.; Arnold, M.; Soerjomataram, I.; O’Doherty, M.G.; Ordonez-Mena, J.M.; Bamia, C.; Kampman, E.; Leitzmann, M.; Romieu, I.; Kee, F.; et al. Comparison of general obesity and measures of body fat distribution in older adults in relation to cancer risk: Meta-analysis of individual participant data of seven prospective cohorts in Europe. Br. J. Cancer 2017, 116, 1486-1497. [CrossRef]

15. Kyrgiou, M.; Kalliala, I.; Markozannes, G.; Gunter, M.J.; Paraskevaidis, E.; Gabra, H.; Martin-Hirsch, P.; Tsilidis, K.K. Adiposity and cancer at major anatomical sites: Umbrella review of the literature. BMJ 2017, 356, j477. [CrossRef]

16. Wang, J.; Yang, D.L.; Chen, Z.Z.; Gou, B.F. Associations of body mass index with cancer incidence among populations, genders, and menopausal status: A systematic review and meta-analysis. Cancer Epidemiol 2016, 42, 1-8. [CrossRef]

17. Premenopausal Breast Cancer Collaborative Group; Schoemaker, M.J.; Nichols, H.B.; Wright, L.B.; Brook, M.N.; Jones, M.E.; O’Brien, K.M.; Adami, H.O.; Baglietto, L.; Bernstein, L.; et al. Association of Body Mass Index and Age With Subsequent Breast Cancer Risk in Premenopausal Women. JAMA Oncol 2018, 4, e181771. [CrossRef]

18. Ayoub, N.M.; Yaghan, R.J.; Abdo, N.M.; Matalka, I.I.; Akhu-Zaheya, L.M.; Al-Mohtaseb, A.H. Impact of Obesity on Clinicopathologic Characteristics and Disease Prognosis in Pre- and Postmenopausal Breast Cancer Patients: A Retrospective Institutional Study. J. Obes. 2019, 2019, 3820759. [CrossRef]

19. Blair, C.K.; Wiggins, C.L.; Nibbe, A.M.; Storlie, C.B.; Prossnitz, E.R.; Royce, M.; Lomo, L.C.; Hill, D.A. Obesity and survival among a cohort of breast cancer patients is partially mediated by tumor characteristics. NPJ Breast Cancer 2019, 5, 33. [CrossRef]

20. Hao, S.; Liu, Y.; Yu, K.D.; Chen, S.; Yang, W.T.; Shao, Z.M. Overweight as a Prognostic Factor for Triple-Negative Breast Cancers in Chinese Women. PLoS ONE 2015, 10, e0129741. [CrossRef]

21. Ademuyiwa, F.O.; Groman, A.; O'Connor, T.; Ambrosone, C.; Watroba, N.; Edge, S.B. Impact of body mass index on clinical outcomes in triple-negative breast cancer. Cancer 2011, 117, 4132-4140. [CrossRef]

22. Chen, L.; Cook, L.S.; Tang, M.T.; Porter, P.L.; Hill, D.A.; Wiggins, C.L.; Li, C.I. Body mass index and risk of luminal, HER2overexpressing, and triple negative breast cancer. Breast Cancer Res. Treat. 2016, 157, 545-554. [CrossRef]

23. Jeong, S.H.; An, Y.; Ahn, C.; Park, B.; Lee, M.H.; Noh, D.Y.; Park, S.K. Body mass index and risk of breast cancer molecular subtypes in Korean women: A case-control study. Breast Cancer Res. Treat. 2020, 179, 459-470. [CrossRef] [PubMed]

24. Bandera, E.V.; Chandran, U.; Hong, C.C.; Troester, M.A.; Bethea, T.N.; Adams-Campbell, L.L.; Haiman, C.A.; Park, S.Y.; Olshan, A.F.; Ambrosone, C.B.; et al. Obesity, body fat distribution, and risk of breast cancer subtypes in African American women participating in the AMBER Consortium. Breast Cancer Res. Treat. 2015, 150, 655-666. [CrossRef] 
25. Canchola, A.J.; Anton-Culver, H.; Bernstein, L.; Clarke, C.A.; Henderson, K.; Ma, H.; Ursin, G.; Horn-Ross, P.L. Body size and the risk of postmenopausal breast cancer subtypes in the California Teachers Study cohort. Cancer Causes Control. 2012. [CrossRef]

26. Kwan, M.L.; Kroenke, C.H.; Sweeney, C.; Bernard, P.S.; Weltzien, E.K.; Castillo, A.; Factor, R.E.; Maxfield, K.S.; Stijleman, I.J.; Kushi, L.H.; et al. Association of high obesity with PAM50 breast cancer intrinsic subtypes and gene expression. BMC Cancer 2015, 15, 278. [CrossRef]

27. Mamidi, T.K.K.; Wu, J.; Tchounwou, P.B.; Miele, L.; Hicks, C. Whole Genome Transcriptome Analysis of the Association between Obesity and Triple-Negative Breast Cancer in Caucasian Women. Int. J. Environ. Res. Public Health 2018, 15, 2338. [CrossRef]

28. Bluher, M. Adipose tissue dysfunction in obesity. Exp. Clin. Endocrinol. Diabetes 2009, 117, 241-250. [CrossRef]

29. Ramos-Andrade, I.; Moraes, J.; Brandao-Costa, R.M.; Vargas da Silva, S.; de Souza, A.; da Silva, C.; Renovato-Martins, M.; BarjaFidalgo, C. Obese adipose tissue extracellular vesicles raise breast cancer cell malignancy. Endocr. Relat. Cancer 2020, 27, 571-582. [CrossRef]

30. Wei, X.; Li, S.; He, J.; Du, H.; Liu, Y.; Yu, W.; Hu, H.; Han, L.; Wang, C.; Li, H.; et al. Tumor-secreted PAI-1 promotes breast cancer metastasis via the induction of adipocyte-derived collagen remodeling. Cell Commun. Signal. 2019, 17, 58. [CrossRef]

31. Engin, A. Adipose Tissue Hypoxia in Obesity and Its Impact on Preadipocytes and Macrophages: Hypoxia Hypothesis. Adv. Exp. Med. Biol. 2017, 960, 305-326. [CrossRef] [PubMed]

32. Zhu, Z.; Zhu, X.; Yang, S.; Guo, Z.; Li, K.; Ren, C.; Zhou, Y.; Dou, J. Yin-yang effect of tumour cells in breast cancer: From mechanism of crosstalk between tumour-associated macrophages and cancer-associated adipocytes. Am. J. Cancer Res. 2020, 10, 383-392. [PubMed]

33. Yee, L.D.; Mortimer, J.E.; Natarajan, R.; Dietze, E.C.; Seewaldt, V.L. Metabolic Health, Insulin, and Breast Cancer: Why Oncologists Should Care About Insulin. Front. Endocrinol. (Lausanne) 2020, 11, 58. [CrossRef]

34. Ortega, M.A.; Fraile-Martinez, O.; Asunsolo, A.; Bujan, J.; Garcia-Honduvilla, N.; Coca, S. Signal Transduction Pathways in Breast Cancer: The Important Role of PI3K/Akt/mTOR. J. Oncol. 2020, 2020, 9258396. [CrossRef]

35. Treins, C.; Giorgetti-Peraldi, S.; Murdaca, J.; Semenza, G.L.; Van Obberghen, E. Insulin stimulates hypoxia-inducible factor 1 through a phosphatidylinositol 3-kinase/target of rapamycin-dependent signaling pathway. J. Biol. Chem. 2002, 277, 27975-27981. [CrossRef]

36. Wang, L.; Tang, C.; Cao, H.; Li, K.; Pang, X.; Zhong, L.; Dang, W.; Tang, H.; Huang, Y.; Wei, L.; et al. Activation of IL-8 via PI3K/Akt-dependent pathway is involved in leptin-mediated epithelial-mesenchymal transition in human breast cancer cells. Cancer Biol. Ther. 2015, 16, 1220-1230. [CrossRef]

37. Pascale, R.M.; Calvisi, D.F.; Simile, M.M.; Feo, C.F.; Feo, F. The Warburg Effect 97 Years after Its Discovery. Cancers 2020, $12,2819$. [CrossRef]

38. Lehr, S.; Hartwig, S.; Sell, H. Adipokines: A treasure trove for the discovery of biomarkers for metabolic disorders. Proteomics Clin. Appl. 2012, 6, 91-101. [CrossRef]

39. Booth, A.; Magnuson, A.; Fouts, J.; Foster, M. Adipose tissue, obesity and adipokines: Role in cancer promotion. Horm. Mol. Biol. Clin. Investig. 2015, 21, 57-74. [CrossRef]

40. He, Z.; Bateman, A. Progranulin (granulin-epithelin precursor, PC-cell-derived growth factor, acrogranin) mediates tissue repair and tumorigenesis. J. Mol. Med. 2003, 81, 600-612. [CrossRef]

41. Matsubara, T.; Mita, A.; Minami, K.; Hosooka, T.; Kitazawa, S.; Takahashi, K.; Tamori, Y.; Yokoi, N.; Watanabe, M.; Matsuo, E.; et al PGRN is a key adipokine mediating high fat diet-induced insulin resistance and obesity through IL-6 in adipose tissue. Cell Metab. 2012, 15, 38-50. [CrossRef]

42. Tangkeangsirisin, W.; Serrero, G. PC cell-derived growth factor (PCDGF/GP88, progranulin) stimulates migration, invasiveness and VEGF expression in breast cancer cells. Carcinogenesis 2004, 25, 1587-1592. [CrossRef] [PubMed]

43. Tkaczuk, K.H.R.; Hawkins, D.; Yue, B.; Hicks, D.; Tait, N.; Serrero, G. Association of Serum Progranulin Levels With Disease Progression, Therapy Response and Survival in Patients With Metastatic Breast Cancer. Clin. Breast Cancer 2020, 20, $220-227$. [CrossRef] [PubMed]

44. Wong, G.W.; Wang, J.; Hug, C.; Tsao, T.S.; Lodish, H.F. A family of Acrp30/adiponectin structural and functional paralogs. Proc. Natl. Acad. Sci. USA 2004, 101, 10302-10307. [CrossRef]

45. Di Zazzo, E.; Polito, R.; Bartollino, S.; Nigro, E.; Porcile, C.; Bianco, A.; Daniele, A.; Moncharmont, B. Adiponectin as Link Factor between Adipose Tissue and Cancer. Int. J. Mol. Sci. 2019, 20, 839. [CrossRef]

46. Hosogai, N.; Fukuhara, A.; Oshima, K.; Miyata, Y.; Tanaka, S.; Segawa, K.; Furukawa, S.; Tochino, Y.; Komuro, R.; Matsuda, M.; et al. Adipose tissue hypoxia in obesity and its impact on adipocytokine dysregulation. Diabetes 2007, 56, 901-911. [CrossRef]

47. Yu, Z.; Tang, S.; Ma, H.; Duan, H.; Zeng, Y. Association of serum adiponectin with breast cancer: A meta-analysis of 27 case-control studies. Medicine 2019, 98, e14359. [CrossRef]

48. Arditi, J.D.; Venihaki, M.; Karalis, K.P.; Chrousos, G.P. Antiproliferative effect of adiponectin on MCF7 breast cancer cells: A potential hormonal link between obesity and cancer. Horm. Metab. Res. 2007, 39, 9-13. [CrossRef]

49. Dos Santos, E.; Benaitreau, D.; Dieudonne, M.N.; Leneveu, M.C.; Serazin, V.; Giudicelli, Y.; Pecquery, R. Adiponectin mediates an antiproliferative response in human MDA-MB 231 breast cancer cells. Oncol. Rep. 2008, 20, 971-977. 
50. Nakayama, S.; Miyoshi, Y.; Ishihara, H.; Noguchi, S. Growth-inhibitory effect of adiponectin via adiponectin receptor 1 on human breast cancer cells through inhibition of S-phase entry without inducing apoptosis. Breast Cancer Res. Treat. 2008, 112, 405-410. [CrossRef]

51. Yamauchi, T.; Kamon, J.; Ito, Y.; Tsuchida, A.; Yokomizo, T.; Kita, S.; Sugiyama, T.; Miyagishi, M.; Hara, K.; Tsunoda, M.; et al. Cloning of adiponectin receptors that mediate antidiabetic metabolic effects. Nature 2003, 423, 762-769. [CrossRef] [PubMed]

52. Cao, W.; Li, J.; Hao, Q.; Vadgama, J.V.; Wu, Y. AMP-activated protein kinase: A potential therapeutic target for triple-negative breast cancer. Breast Cancer Res. 2019, 21, 29. [CrossRef] [PubMed]

53. Shackelford, D.B.; Shaw, R.J. The LKB1-AMPK pathway: Metabolism and growth control in tumour suppression. Nat. Rev. Cancer 2009, 9, 563-575. [CrossRef] [PubMed]

54. Grossmann, M.E.; Nkhata, K.J.; Mizuno, N.K.; Ray, A.; Cleary, M.P. Effects of adiponectin on breast cancer cell growth and signaling. Br. J. Cancer 2008, 98, 370-379. [CrossRef]

55. Brown, K.A.; Simpson, E.R. Obesity and breast cancer: Progress to understanding the relationship. Cancer Res. 2010, 70, 4-7. [CrossRef]

56. Chandran, K.; Goswami, S.; Sharma-Walia, N. Implications of a peroxisome proliferator-activated receptor alpha (PPAR $\alpha)$ ligand clofibrate in breast cancer. Oncotarget 2015, 7, 23.

57. Lecarpentier, Y.; Claes, V.; Vallee, A.; Hebert, J.L. Thermodynamics in cancers: Opposing interactions between PPAR gamma and the canonical WNT/beta-catenin pathway. Clin. Transl. Med. 2017, 6, 14. [CrossRef]

58. Mauro, L.; Naimo, G.D.; Gelsomino, L.; Malivindi, R.; Bruno, L.; Pellegrino, M.; Tarallo, R.; Memoli, D.; Weisz, A.; Panno, M.L.; et al. Uncoupling effects of estrogen receptor alpha on LKB1/AMPK interaction upon adiponectin exposure in breast cancer. FASEB J. 2018, 32, 4343-4355. [CrossRef]

59. Mauro, L.; Pellegrino, M.; De Amicis, F.; Ricchio, E.; Giordano, F.; Rizza, P.; Catalano, S.; Bonofiglio, D.; Sisci, D.; Panno, M.L.; et al. Evidences that estrogen receptor alpha interferes with adiponectin effects on breast cancer cell growth. Cell Cycle 2014, 13, 553-564. [CrossRef]

60. Mauro, L.; Pellegrino, M.; Giordano, F.; Ricchio, E.; Rizza, P.; De Amicis, F.; Catalano, S.; Bonofiglio, D.; Panno, M.L.; Ando, S. Estrogen receptor-alpha drives adiponectin effects on cyclin D1 expression in breast cancer cells. FASEB J. 2015, 29, $2150-2160$. [CrossRef]

61. Naimo, G.D.; Gelsomino, L.; Catalano, S.; Mauro, L.; Ando, S. Interfering Role of ERalpha on Adiponectin Action in Breast Cancer. Front. Endocrinol. (Lausanne) 2020, 11, 66. [CrossRef]

62. Pfeiler, G.H.; Buechler, C.; Neumeier, M.; Schaffler, A.; Schmitz, G.; Ortmann, O.; Treeck, O. Adiponectin effects on human breast cancer cells are dependent on 17-beta estradiol. Oncol. Rep. 2008, 19, 787-793.

63. Landskroner-Eiger, S.; Qian, B.; Muise, E.S.; Nawrocki, A.R.; Berger, J.P.; Fine, E.J.; Koba, W.; Deng, Y.; Pollard, J.W.; Scherer, P.E. Proangiogenic contribution of adiponectin toward mammary tumor growth in vivo. Clin. Cancer Res. 2009, 15, 3265-3276. [CrossRef]

64. Markowska, A.; Malendowicz, K.; Drews, K. The role of leptin in breast cancer. Eur. J. Gynaecol Oncol. 2004, 25, $192-194$.

65. Friedman, J.M.; Halaas, J.L. Leptin and the regulation of body weight in mammals. Nature 1998, 395, 763-770. [CrossRef]

66. Himbert, C.; Delphan, M.; Scherer, D.; Bowers, L.W.; Hursting, S.; Ulrich, C.M. Signals from the Adipose Microenvironment and the Obesity-Cancer Link-A Systematic Review. Cancer Prev. Res. (Phila) 2017, 10, 494-506. [CrossRef]

67. Ishikawa, M.; Kitayama, J.; Nagawa, H. Enhanced expression of leptin and leptin receptor (OB-R) in human breast cancer. Clin. Cancer Res. 2004, 10, 4325-4331. [CrossRef]

68. Pan, H.; Deng, L.L.; Cui, J.Q.; Shi, L.; Yang, Y.C.; Luo, J.H.; Qin, D.; Wang, L. Association between serum leptin levels and breast cancer risk: An updated systematic review and meta-analysis. Medicine 2018, 97, e11345. [CrossRef]

69. Rodrigo, C.; Tennekoon, K.H.; Karunanayake, E.H.; De Silva, K.; Amarasinghe, I.; Wijayasiri, A. Circulating leptin, soluble leptin receptor, free leptin index, visfatin and selected leptin and leptin receptor gene polymorphisms in sporadic breast cancer. Endocr. J. 2017, 64, 393-401. [CrossRef]

70. Khabaz, M.N.; Abdelrahman, A.; Butt, N.; Damnhory, L.; Elshal, M.; Aldahlawi, A.M.; Ashoor, S.; Al-Maghrabi, B.; Dobson, P.; Brown, B.; et al. Immunohistochemical staining of leptin is associated with grade, stage, lymph node involvement, recurrence, and hormone receptor phenotypes in breast cancer. BMC Womens Health 2017, 17, 105. [CrossRef]

71. Giordano, C.; Chemi, F.; Panza, S.; Barone, I.; Bonofiglio, D.; Lanzino, M.; Cordella, A.; Campana, A.; Hashim, A.; Rizza, P.; et al. Leptin as a mediator of tumor-stromal interactions promotes breast cancer stem cell activity. Oncotarget 2016, 7 , 1262-1275. [CrossRef]

72. Linares, R.L.; Benitez, J.G.S.; Reynoso, M.O.; Romero, C.G.; Sandoval-Cabrera, A. Modulation of the leptin receptors expression in breast cancer cell lines exposed to leptin and tamoxifen. Sci. Rep. 2019, 9, 19189. [CrossRef]

73. Ray, A.; Nkhata, K.J.; Cleary, M.P. Effects of leptin on human breast cancer cell lines in relationship to estrogen receptor and HER2 status. Int. J. Oncol. 2007, 30, 1499-1509. [CrossRef]

74. Sabol, R.A.; Bowles, A.C.; Cote, A.; Wise, R.; O’Donnell, B.; Matossian, M.D.; Hossain, F.M.; Burks, H.E.; Del Valle, L.; Miele, L.; et al. Leptin produced by obesity-altered adipose stem cells promotes metastasis but not tumorigenesis of triplenegative breast cancer in orthotopic xenograft and patient-derived xenograft models. Breast Cancer Res. 2019, 21, 67. [CrossRef] [PubMed] 
75. Sanchez-Jimenez, F.; Perez-Perez, A.; de la Cruz-Merino, L.; Sanchez-Margalet, V. Obesity and Breast Cancer: Role of Leptin. Front. Oncol. 2019, 9, 596. [CrossRef] [PubMed]

76. Saxena, N.K.; Vertino, P.M.; Anania, F.A.; Sharma, D. leptin-induced growth stimulation of breast cancer cells involves recruitment of histone acetyltransferases and mediator complex to CYCLIN D1 promoter via activation of Stat3. J. Biol. Chem. 2007, 282, 13316-13325. [CrossRef] [PubMed]

77. Yuan, H.J.; Sun, K.W.; Yu, K. Leptin promotes the proliferation and migration of human breast cancer through the extracellularsignal regulated kinase pathway. Mol. Med. Rep. 2014, 9, 350-354. [CrossRef]

78. Catalano, S.; Mauro, L.; Marsico, S.; Giordano, C.; Rizza, P.; Rago, V.; Montanaro, D.; Maggiolini, M.; Panno, M.L.; Ando, S. Leptin induces, via ERK1/ERK2 signal, functional activation of estrogen receptor alpha in MCF-7 cells. J. Biol. Chem. 2004, 279, 19908-19915. [CrossRef]

79. Zahid, H.; Subbaramaiah, K.; Iyengar, N.M.; Zhou, X.K.; Chen, I.C.; Bhardwaj, P.; Gucalp, A.; Morrow, M.; Hudis, C.A.; Dannenberg, A.J.; et al. Leptin regulation of the p53-HIF1alpha/PKM2-aromatase axis in breast adipose stromal cells: A novel mechanism for the obesity-breast cancer link. Int. J. Obes. 2018, 42, 711-720. [CrossRef]

80. Gonzalez-Perez, R.R.; Xu, Y.; Guo, S.; Watters, A.; Zhou, W.; Leibovich, S.J. Leptin upregulates VEGF in breast cancer via canonic and non-canonical signalling pathways and NFkappaB/HIF-1alpha activation. Cell Signal. 2010, 22, 1350-1362. [CrossRef]

81. He, J.Y.; Wei, X.H.; Li, S.J.; Liu, Y.; Hu, H.L.; Li, Z.Z.; Kuang, X.H.; Wang, L.; Shi, X.; Yuan, S.T.; et al. Adipocyte-derived IL-6 and leptin promote breast Cancer metastasis via upregulation of Lysyl Hydroxylase-2 expression. Cell Commun. Signal. 2018, 16, 100. [CrossRef]

82. Huang, Y.; Jin, Q.; Su, M.; Ji, F.; Wang, N.; Zhong, C.; Jiang, Y.; Liu, Y.; Zhang, Z.; Yang, J.; et al. Leptin promotes the migration and invasion of breast cancer cells by upregulating ACAT2. Cell Oncol. (Dordr) 2017, 40, 537-547. [CrossRef]

83. Park, J.W.; Zhao, L.; Willingham, M.C.; Cheng, S.Y. Inhibition of STAT3 signaling blocks obesity-induced mammary hyperplasia in a mouse model. Am. J. Cancer Res. 2017, 7, 727-739.

84. Basu, S.; Nachat-Kappes, R.; Caldefie-Chezet, F.; Vasson, M.P. Eicosanoids and adipokines in breast cancer: From molecular mechanisms to clinical considerations. Antioxid Redox Signal. 2013, 18, 323-360. [CrossRef]

85. Chang, C.C.; Wu, M.J.; Yang, J.Y.; Camarillo, I.G.; Chang, C.J. Leptin-STAT3-G9a Signaling Promotes Obesity-Mediated Breast Cancer Progression. Cancer Res. 2015, 75, 2375-2386. [CrossRef] [PubMed]

86. Dorgan, J.F.; Stanczyk, F.Z.; Kahle, L.L.; Brinton, L.A. Prospective case-control study of premenopausal serum estradiol and testosterone levels and breast cancer risk. Breast Cancer Res. 2010, 12, R98. [CrossRef] [PubMed]

87. Honma, N.; Saji, S.; Hirose, M.; Horiguchi, S.; Kuroi, K.; Hayashi, S.; Utsumi, T.; Harada, N. Sex steroid hormones in pairs of tumor and serum from breast cancer patients and pathobiological role of androstene-3beta, 17beta-diol. Cancer Sci. 2011, 102, 1848-1854. [CrossRef]

88. Sikora, M.J.; Strumba, V.; Lippman, M.E.; Johnson, M.D.; Rae, J.M. Mechanisms of estrogen-independent breast cancer growth driven by low estrogen concentrations are unique versus complete estrogen deprivation. Breast Cancer Res. Treat. 2012, 134, 1027-1039. [CrossRef]

89. Doane, A.S.; Danso, M.; Lal, P.; Donaton, M.; Zhang, L.; Hudis, C.; Gerald, W.L. An estrogen receptor-negative breast cancer subset characterized by a hormonally regulated transcriptional program and response to androgen. Oncogene 2006, 25, 3994-4008. [CrossRef]

90. Rangel, N.; Rondon-Lagos, M.; Annaratone, L.; Aristizabal-Pachon, A.F.; Cassoni, P.; Sapino, A.; Castellano, I. AR/ER Ratio Correlates with Expression of Proliferation Markers and with Distinct Subset of Breast Tumors. Cells 2020, 9, 1064. [CrossRef]

91. Burger, H.G. Androgen production in women. Fertil. Steril. 2002, 77 (Suppl. S4), S3-S5. [CrossRef]

92. Narayanan, R.; Coss, C.C.; Dalton, J.T. Development of selective androgen receptor modulators (SARMs). Mol. Cell Endocrinol. 2018, 465, 134-142. [CrossRef]

93. Baglietto, L.; Severi, G.; English, D.R.; Krishnan, K.; Hopper, J.L.; McLean, C.; Morris, H.A.; Tilley, W.D.; Giles, G.G. Circulating steroid hormone levels and risk of breast cancer for postmenopausal women. Cancer Epidemiol. Biomarkers Prev. 2010, 19, 492-502. [CrossRef] [PubMed]

94. Woolcott, C.G.; Shvetsov, Y.B.; Stanczyk, F.Z.; Wilkens, L.R.; White, K.K.; Caberto, C.; Henderson, B.E.; Le Marchand, L.; Kolonel, L.N.; Goodman, M.T. Plasma sex hormone concentrations and breast cancer risk in an ethnically diverse population of postmenopausal women: The Multiethnic Cohort Study. Endocr. Relat. Cancer 2010, 17, 125-134. [CrossRef]

95. Zeleniuch-Jacquotte, A.; Afanasyeva, Y.; Kaaks, R.; Rinaldi, S.; Scarmo, S.; Liu, M.; Arslan, A.A.; Toniolo, P.; Shore, R.E.; Koenig, K.L. Premenopausal serum androgens and breast cancer risk: A nested case-control study. Breast Cancer Res. 2012, 14, R32. [CrossRef]

96. Kensler, K.H.; Eliassen, A.H.; Rosner, B.A.; Hankinson, S.E.; Brown, M.; Tamimi, R.M. Pre-diagnostic sex hormone levels and survival among breast cancer patients. Breast Cancer Res. Treat. 2019, 174, 749-758. [CrossRef]

97. Castellano, I.; Allia, E.; Accortanzo, V.; Vandone, A.M.; Chiusa, L.; Arisio, R.; Durando, A.; Donadio, M.; Bussolati, G.; Coates, A.S.; et al. Androgen receptor expression is a significant prognostic factor in estrogen receptor positive breast cancers. Breast Cancer Res. Treat. 2010, 124, 607-617. [CrossRef]

98. Yang, Y.; Min, A.; Lee, K.H.; Ryu, H.S.; Kim, T.Y.; Woo, G.U.; Suh, K.J.; Lee, D.W.; Lee, H.B.; Moon, H.G.; et al. Prognostic Role of Androgen Receptor Expression in Surgically Resected Early Breast Cancer Patients. J. Breast Cancer 2020, 23, 182-193. [CrossRef] 
99. Bozovic-Spasojevic, I.; Zardavas, D.; Brohee, S.; Ameye, L.; Fumagalli, D.; Ades, F.; de Azambuja, E.; Bareche, Y.; Piccart, M.; Paesmans, M.; et al. The Prognostic Role of Androgen Receptor in Patients with Early-Stage Breast Cancer: A Meta-analysis of Clinical and Gene Expression Data. Clin. Cancer Res. 2016. [CrossRef]

100. Ricciardelli, C.; Bianco-Miotto, T.; Jindal, S.; Butler, L.M.; Leung, S.; McNeil, C.M.; O’Toole, S.A.; Ebrahimie, E.; Millar, E.K.A.; Sakko, A.J.; et al. The Magnitude of Androgen Receptor Positivity in Breast Cancer Is Critical for Reliable Prediction of Disease Outcome. Clin. Cancer Res. 2018, 24, 2328-2341. [CrossRef]

101. Vera-Badillo, F.E.; Templeton, A.J.; de Gouveia, P.; Diaz-Padilla, I.; Bedard, P.L.; Al-Mubarak, M.; Seruga, B.; Tannock, I.F.; Ocana, A.; Amir, E. Androgen receptor expression and outcomes in early breast cancer: A systematic review and meta-analysis. J. Natl. Cancer Inst. 2014, 106, djt319. [CrossRef] [PubMed]

102. Park, S.; Koo, J.; Park, H.S.; Kim, J.H.; Choi, S.Y.; Lee, J.H.; Park, B.W.; Lee, K.S. Expression of androgen receptors in primary breast cancer. Ann. Oncol. 2010, 21, 488-492. [CrossRef] [PubMed]

103. Govindan, S.; Siraganahalli Eswaraiah, M.; Basavaraj, C.; Adinarayan, M.; Sankaran, S.; Bakre, M. Androgen Receptor mRNA levels determine the prognosis in triple-negative breast cancer patients. BMC Cancer 2020, 20, 745. [CrossRef] [PubMed]

104. Zhang, X.; Eliassen, A.H.; Tamimi, R.M.; Hazra, A.; Beck, A.H.; Brown, M.; Collins, L.C.; Rosner, B.; Hankinson, S.E. Adult body size and physical activity in relation to risk of breast cancer according to tumor androgen receptor status. Cancer Epidemiol. Biomarkers Prev. 2015, 24, 962-968. [CrossRef]

105. Hilborn, E.; Gacic, J.; Fornander, T.; Nordenskjold, B.; Stal, O.; Jansson, A. Androgen receptor expression predicts beneficial tamoxifen response in oestrogen receptor-alpha-negative breast cancer. Br. J. Cancer 2016, 114, 248-255. [CrossRef]

106. Luo, X.; Shi, Y.X.; Li, Z.M.; Jiang, W.Q. Expression and clinical significance of androgen receptor in triple negative breast cancer. Chin. J. Cancer 2010, 29, 585-590. [CrossRef]

107. Van de Stolpe, A.; Wesseling-Rozendaal, Y.; Alves de Inda, M.; Van Ooijen, H.; Verhaegh, W. Androgen receptor pathway activity and the ratio between androgen and estrogen receptor pathway activity in breast cancer subtypes. In Proceedings of the San Antonio Breast Cancer Symposium, San Antonio, TX, USA, 14 February 2020; AACR publications: Philadelphia, PA, USA, 2020.

108. Anestis, A.; Zoi, I.; Papavassiliou, A.G.; Karamouzis, M.V. Androgen Receptor in Breast Cancer-Clinical and Preclinical Research Insights. Molecules 2020, 25, 358. [CrossRef]

109. Claessens, F.; Verrijdt, G.; Schoenmakers, E.; Haelens, A.; Peeters, B.; Verhoeven, G.; Rombauts, W. Selective DNA binding by the androgen receptor as a mechanism for hormone-specific gene regulation. J. Steroid Biochem Mol. Biol. 2001, 76, 23-30. [CrossRef]

110. Heinlein, C.A.; Chang, C. The roles of androgen receptors and androgen-binding proteins in nongenomic androgen actions. Mol. Endocrinol. 2002, 16, 2181-2187. [CrossRef]

111. Birrell, S.N.; Bentel, J.M.; Hickey, T.E.; Ricciardelli, C.; Weger, M.A.; Horsfall, D.J.; Tilley, W.D. Androgens induce divergent proliferative responses in human breast cancer cell lines. J. Steroid Biochem. Mol. Biol. 1995, 52, 459-467. [CrossRef]

112. Ho, Y.; Li, Z.L.; Shih, Y.J.; Chen, Y.R.; Wang, K.; Whang-Peng, J.; Lin, H.Y.; Davis, P.J. Integrin alphavbeta3 in the Mediating Effects of Dihydrotestosterone and Resveratrol on Breast Cancer Cell Proliferation. Int. J. Mol. Sci. 2020, 21, 2906. [CrossRef]

113. Sonne-Hansen, K.; Lykkesfeldt, A.E. Endogenous aromatization of testosterone results in growth stimulation of the human MCF-7 breast cancer cell line. J. Steroid Biochem. Mol. Biol. 2005, 93, 25-34. [CrossRef]

114. Macedo, L.F.; Guo, Z.; Tilghman, S.L.; Sabnis, G.J.; Qiu, Y.; Brodie, A. Role of androgens on MCF-7 breast cancer cell growth and on the inhibitory effect of letrozole. Cancer Res. 2006, 66, 7775-7782. [CrossRef]

115. Cops, E.J.; Bianco-Miotto, T.; Moore, N.L.; Clarke, C.L.; Birrell, S.N.; Butler, L.M.; Tilley, W.D. Antiproliferative actions of the synthetic androgen, mibolerone, in breast cancer cells are mediated by both androgen and progesterone receptors. J. Steroid Biochem. Mol. Biol. 2008, 110, 236-243. [CrossRef]

116. Ortmann, J.; Prifti, S.; Bohlmann, M.K.; Rehberger-Schneider, S.; Strowitzki, T.; Rabe, T. Testosterone and 5 alphadihydrotestosterone inhibit in vitro growth of human breast cancer cell lines. Gynecol. Endocrinol. 2002, 16, 113-120. [CrossRef]

117. Moon, J.Y.; McNamara, K.M.; Lee, J.J.; Chung, B.C.; Sasano, H.; Choi, M.H. Improved detectability of sex steroids from frozen sections of breast cancer tissue using GC-triple quadrupole-MS. J. Steroid Biochem. Mol. Biol. 2018, 178, 185-192. [CrossRef]

118. Velie, E.M.; Nechuta, S.; Osuch, J.R. Lifetime reproductive and anthropometric risk factors for breast cancer in postmenopausal women. Breast Dis. 2005, 24, 17-35. [CrossRef]

119. Kandouz, M.; Lombet, A.; Perrot, J.Y.; Jacob, D.; Carvajal, S.; Kazem, A.; Rostene, W.; Therwath, A.; Gompel, A. Proapoptotic effects of antiestrogens, progestins and androgen in breast cancer cells. J. Steroid Biochem. Mol. Biol. 1999, 69, 463-471. [CrossRef]

120. Peters, A.A.; Buchanan, G.; Ricciardelli, C.; Bianco-Miotto, T.; Centenera, M.M.; Harris, J.M.; Jindal, S.; Segara, D.; Jia, L.; Moore, N.L.; et al. Androgen receptor inhibits estrogen receptor-alpha activity and is prognostic in breast cancer. Cancer Res. 2009, 69, 6131-6140. [CrossRef]

121. Lanzino, M.; Sisci, D.; Morelli, C.; Garofalo, C.; Catalano, S.; Casaburi, I.; Capparelli, C.; Giordano, C.; Giordano, F.; Maggiolini, M.; et al. Inhibition of cyclin D1 expression by androgen receptor in breast cancer cells-identification of a novel androgen response element. Nucleic Acids Res. 2010, 38, 5351-5365. [CrossRef]

122. Wang, Y.; He, X.; Yu, Q.; Eng, C. Androgen receptor-induced tumor suppressor, KLLN, inhibits breast cancer growth and transcriptionally activates p53/p73-mediated apoptosis in breast carcinomas. Hum. Mol. Genet. 2013, 22, 2263-2272. [CrossRef] [PubMed] 
123. Wang, Y.; Romigh, T.; He, X.; Tan, M.H.; Orloff, M.S.; Silverman, R.H.; Heston, W.D.; Eng, C. Differential regulation of PTEN expression by androgen receptor in prostate and breast cancers. Oncogene 2011, 30, 4327-4338. [CrossRef] [PubMed]

124. Lanzino, M.; De Amicis, F.; McPhaul, M.J.; Marsico, S.; Panno, M.L.; Ando, S. Endogenous coactivator ARA70 interacts with estrogen receptor alpha (ERalpha) and modulates the functional ERalpha/androgen receptor interplay in MCF-7 cells. J. Biol. Chem. 2005, 280, 20421-20430. [CrossRef] [PubMed]

125. Need, E.F.; Selth, L.A.; Harris, T.J.; Birrell, S.N.; Tilley, W.D.; Buchanan, G. Research resource: Interplay between the genomic and transcriptional networks of androgen receptor and estrogen receptor alpha in luminal breast cancer cells. Mol. Endocrinol. 2012, 26, 1941-1952. [CrossRef]

126. Lanzino, M.; Maris, P.; Sirianni, R.; Barone, I.; Casaburi, I.; Chimento, A.; Giordano, C.; Morelli, C.; Sisci, D.; Rizza, P.; et al. DAX-1, as an androgen-target gene, inhibits aromatase expression: A novel mechanism blocking estrogen-dependent breast cancer cell proliferation. Cell Death. Dis. 2013, 4, e724. [CrossRef]

127. Ciupek, A.; Rechoum, Y.; Gu, G.; Gelsomino, L.; Beyer, A.R.; Brusco, L.; Covington, K.R.; Tsimelzon, A.; Fuqua, S.A. Androgen receptor promotes tamoxifen agonist activity by activation of EGFR in ERalpha-positive breast cancer. Breast Cancer Res. Treat. 2015, 154, 225-237. [CrossRef]

128. Migliaccio, A.; Di Domenico, M.; Castoria, G.; Nanayakkara, M.; Lombardi, M.; de Falco, A.; Bilancio, A.; Varricchio, L.; Ciociola, A.; Auricchio, F. Steroid receptor regulation of epidermal growth factor signaling through Src in breast and prostate cancer cells: Steroid antagonist action. Cancer Res. 2005, 65, 10585-10593. [CrossRef]

129. Shou, J.; Massarweh, S.; Osborne, C.K.; Wakeling, A.E.; Ali, S.; Weiss, H.; Schiff, R. Mechanisms of tamoxifen resistance: Increased estrogen receptor-HER2/neu cross-talk in ER/HER2-positive breast cancer. J. Natl. Cancer Inst. 2004, 96, 926-935. [CrossRef]

130. Thrane, S.; Lykkesfeldt, A.E.; Larsen, M.S.; Sorensen, B.S.; Yde, C.W. Estrogen receptor alpha is the major driving factor for growth in tamoxifen-resistant breast cancer and supported by HER/ERK signaling. Breast Cancer Res. Treat. 2013, 139, 71-80. [CrossRef]

131. Chia, K.; Milioli, H.; Portman, N.; Laven-Law, G.; Coulson, R.; Yong, A.; Segara, D.; Parker, A.; Caldon, C.E.; Deng, N.; et al. Non-canonical AR activity facilitates endocrine resistance in breast cancer. Endocr. Relat. Cancer 2019, 26, 251-264. [CrossRef]

132. De Amicis, F.; Thirugnansampanthan, J.; Cui, Y.; Selever, J.; Beyer, A.; Parra, I.; Weigel, N.L.; Herynk, M.H.; Tsimelzon, A.; Lewis, M.T.; et al. Androgen receptor overexpression induces tamoxifen resistance in human breast cancer cells. Breast Cancer Res. Treat. 2010, 121, 1-11. [CrossRef]

133. Fujii, R.; Hanamura, T.; Suzuki, T.; Gohno, T.; Shibahara, Y.; Niwa, T.; Yamaguchi, Y.; Ohnuki, K.; Kakugawa, Y.; Hirakawa, H.; et al. Increased androgen receptor activity and cell proliferation in aromatase inhibitor-resistant breast carcinoma. J. Steroid Biochem. Mol. Biol. 2014, 144 Pt B, 513-522. [CrossRef]

134. Rechoum, Y.; Rovito, D.; Iacopetta, D.; Barone, I.; Ando, S.; Weigel, N.L.; O’Malley, B.W.; Brown, P.H.; Fuqua, S.A. AR collaborates with ERalpha in aromatase inhibitor-resistant breast cancer. Breast Cancer Res. Treat. 2014, 147, 473-485. [CrossRef]

135. Cochrane, D.R.; Bernales, S.; Jacobsen, B.M.; Cittelly, D.M.; Howe, E.N.; D’Amato, N.C.; Spoelstra, N.S.; Edgerton, S.M.; Jean, A.; Guerrero, J.; et al. Role of the androgen receptor in breast cancer and preclinical analysis of enzalutamide. Breast Cancer Res. 2014, 16, R7. [CrossRef]

136. Rangel, N.; Rondon-Lagos, M.; Annaratone, L.; Osella-Abate, S.; Metovic, J.; Mano, M.P.; Bertero, L.; Cassoni, P.; Sapino, A.; Castellano, I. The role of the AR/ER ratio in ER-positive breast cancer patients. Endocr. Relat. Cancer 2018, 25, 163-172. [CrossRef]

137. Coss, C.C.; Jones, A.; Dalton, J.T. Selective androgen receptor modulators as improved androgen therapy for advanced breast cancer. Steroids 2014, 90, 94-100. [CrossRef]

138. Narayanan, R.; Ahn, S.; Cheney, M.D.; Yepuru, M.; Miller, D.D.; Steiner, M.S.; Dalton, J.T. Selective androgen receptor modulators (SARMs) negatively regulate triple-negative breast cancer growth and epithelial:mesenchymal stem cell signaling. PLoS ONE 2014, 9, e103202. [CrossRef]

139. Lu, Q.; Xia, W.; Lee, K.; Zhang, J.; Yuan, H.; Yuan, Z.; Shi, Y.; Wang, S.; Xu, F. Bicalutamide plus Aromatase Inhibitor in Patients with Estrogen Receptor-Positive/Androgen Receptor-Positive Advanced Breast Cancer. Oncologist 2020, 25, 21-e15. [CrossRef]

140. Krop, I.; Abramson, V.; Colleoni, M.; Traina, T.; Holmes, F.; Garcia-Estevez, L.; Hart, L.; Awada, A.; Zamagni, C.; Morris, P.G.; et al. A Randomized Placebo Controlled Phase II Trial Evaluating Exemestane with or without Enzalutamide in Patients with Hormone Receptor-Positive Breast Cancer. Clin. Cancer Res. 2020, 26, 6149-6157. [CrossRef]

141. Liu, D. AR pathway activity correlates with AR expression in a HER2-dependent manner and serves as a better prognostic factor in breast cancer. Cell Oncol. (Dordr) 2020, 43, 321-333. [CrossRef]

142. Hackenberg, R.; Luttchens, S.; Hofmann, J.; Kunzmann, R.; Holzel, F.; Schulz, K.D. Androgen sensitivity of the new human breast cancer cell line MFM-223. Cancer Res. 1991, 51, 5722-5727.

143. Lehmann, B.D.; Bauer, J.A.; Chen, X.; Sanders, M.E.; Chakravarthy, A.B.; Shyr, Y.; Pietenpol, J.A. Identification of human triplenegative breast cancer subtypes and preclinical models for selection of targeted therapies. J. Clin. Investig. 2011, 121, $2750-2767$. [CrossRef]

144. Robinson, J.L.; Macarthur, S.; Ross-Innes, C.S.; Tilley, W.D.; Neal, D.E.; Mills, I.G.; Carroll, J.S. Androgen receptor driven transcription in molecular apocrine breast cancer is mediated by FoxA1. EMBO J. 2011, 30, 3019-3027. [CrossRef]

145. Barton, V.N.; D'Amato, N.C.; Gordon, M.A.; Lind, H.T.; Spoelstra, N.S.; Babbs, B.L.; Heinz, R.E.; Elias, A.; Jedlicka, P.; Jacobsen, B.M.; et al. Multiple molecular subtypes of triple-negative breast cancer critically rely on androgen receptor and respond to enzalutamide in vivo. Mol. Cancer. Ther. 2015, 14, 769-778. [CrossRef] 
146. Gonzalez-Angulo, A.M.; Stemke-Hale, K.; Palla, S.L.; Carey, M.; Agarwal, R.; Meric-Berstam, F.; Traina, T.A.; Hudis, C.; Hortobagyi, G.N.; Gerald, W.L.; et al. Androgen receptor levels and association with PIK3CA mutations and prognosis in breast cancer. Clin. Cancer Res. 2009, 15, 2472-2478. [CrossRef]

147. Cuenca-Lopez, M.D.; Montero, J.C.; Morales, J.C.; Prat, A.; Pandiella, A.; Ocana, A. Phospho-kinase profile of triple negative breast cancer and androgen receptor signaling. BMC Cancer 2014, 14, 302. [CrossRef]

148. Zhou, Y.; Bolton, E.C.; Jones, J.O. Androgens and androgen receptor signaling in prostate tumorigenesis. J. Mol. Endocrinol. 2015, 54, R15-R29. [CrossRef] [PubMed]

149. Bareche, Y.; Buisseret, L.; Gruosso, T.; Girard, E.; Venet, D.; Dupont, F.; Desmedt, C.; Larsimont, D.; Park, M.; Rothe, F.; et al. Unraveling Triple-Negative Breast Cancer Tumor Microenvironment Heterogeneity: Towards an Optimized Treatment Approach. J. Natl. Cancer Inst. 2020, 112, 708-719. [CrossRef]

150. Teschendorff, A.E.; Miremadi, A.; Pinder, S.E.; Ellis, I.O.; Caldas, C. An immune response gene expression module identifies a good prognosis subtype in estrogen receptor negative breast cancer. Genome Biol. 2007, 8, R157. [CrossRef]

151. Vranic, S.; Marchio, C.; Castellano, I.; Botta, C.; Scalzo, M.S.; Bender, R.P.; Payan-Gomez, C.; di Cantogno, L.V.; Gugliotta, P.; Tondat, F.; et al. Immunohistochemical and molecular profiling of histologically defined apocrine carcinomas of the breast. Hum. Pathol. 2015, 46, 1350-1359. [CrossRef]

152. Coussy, F.; Lavigne, M.; de Koning, L.; Botty, R.E.; Nemati, F.; Naguez, A.; Bataillon, G.; Ouine, B.; Dahmani, A.; Montaudon, E.; et al. Response to $\mathrm{mTOR}$ and PI3K inhibitors in enzalutamide-resistant luminal androgen receptor triple-negative breast cancer patient-derived xenografts. Theranostics 2020, 10, 1531-1543. [CrossRef] [PubMed]

153. Lehmann-Che, J.; Hamy, A.S.; Porcher, R.; Barritault, M.; Bouhidel, F.; Habuellelah, H.; Leman-Detours, S.; de Roquancourt, A.; Cahen-Doidy, L.; Bourstyn, E.; et al. Molecular apocrine breast cancers are aggressive estrogen receptor negative tumors overexpressing either HER2 or GCDFP15. Breast Cancer Res. 2013, 15, R37. [CrossRef]

154. Chen, M.; Yang, Y.; Xu, K.; Li, L.; Huang, J.; Qiu, F. Androgen Receptor in Breast Cancer: From Bench to Bedside. Front. Endocrinol. (Lausanne) 2020, 11, 573. [CrossRef] [PubMed]

155. Gerratana, L.; Basile, D.; Buono, G.; De Placido, S.; Giuliano, M.; Minichillo, S.; Coinu, A.; Martorana, F.; De Santo, I.; Del Mastro, L.; et al. Androgen receptor in triple negative breast cancer: A potential target for the targetless subtype. Cancer Treat. Rev. 2018, 68, 102-110. [CrossRef]

156. Michmerhuizen, A.R.; Spratt, D.E.; Pierce, L.J.; Speers, C.W. ARe we there yet? Understanding androgen receptor signaling in breast cancer. NPJ Breast Cancer 2020, 6, 47. [CrossRef]

157. Gucalp, A.; Tolaney, S.; Isakoff, S.J.; Ingle, J.N.; Liu, M.C.; Carey, L.A.; Blackwell, K.; Rugo, H.; Nabell, L.; Forero, A.; et al. Phase ii trial of bicalutamide in patients with androgen receptor-positive, estrogen, receptor-negative metastatic breast cancer. Clin. Cancer Res. 2013, 19, 5505-5512. [CrossRef]

158. Traina, T.A.; Miller, K.; Yardley, D.A.; Eakle, J.; Schwartzberg, L.S.; O’Shaughnessy, J.; Gradishar, W.; Schmid, P.; Winer, E.; Kelly, C.; et al. Enzalutamide for the Treatment of Androgen Receptor-Expressing Triple-Negative Breast Cancer. J. Clin. Oncol. 2018, 36, 884-890. [CrossRef]

159. Lehmann, B.D.; Bauer, J.A.; Schafer, J.M.; Pendleton, C.S.; Tang, L.; Johnson, K.C.; Chen, X.; Balko, J.M.; Gomez, H.; Arteaga, C.L.; et al. PIK3CA mutations in androgen receptor-positive triple negative breast cancer confer sensitivity to the combination of PI3K and androgen receptor inhibitors. Breast Cancer Res. 2014, 16, 406. [CrossRef]

160. Lehmann, B.D.; Abramson, V.G.; Sanders, M.E.; Mayer, E.L.; Haddad, T.C.; Nanda, R.; Van Poznak, C.; Storniolo, A.M.; Nangia, J.R.; Gonzalez-Ericsson, P.I.; et al. TBCRC 032 IB/II Multicenter Study: Molecular Insights to AR Antagonist and PI3K Inhibitor Efficacy in Patients with AR(+) Metastatic Triple-Negative Breast Cancer. Clin. Cancer Res. 2020, 26, $2111-2123$. [CrossRef]

161. Nelson, L.R.; Bulun, S.E. Estrogen production and action. J. Am. Acad. Dermatol. 2001, 45, S116-S124. [CrossRef]

162. Simpson, E.R. Sources of estrogen and their importance. J. Steroid Biochem. Mol. Biol. 2003, 86, 225-230. [CrossRef]

163. Feher, T.; Bodrogi, L.; Vallent, K.; Ribai, Z. Role of human adipose tissue in the production and metabolism of steroid hormones. Endokrinologie 1982, 80, 173-180. [PubMed]

164. Venturelli, E.; Orenti, A.; Fabricio, A.S.C.; Garrone, G.; Agresti, R.; Paolini, B.; Bonini, C.; Gion, M.; Berrino, F.; Desmedt, C.; et al. Observational study on the prognostic value of testosterone and adiposity in postmenopausal estrogen receptor positive breast cancer patients. BMC Cancer 2018, 18, 651. [CrossRef]

165. Krusinska, B.; Wadolowska, L.; Slowinska, M.A.; Biernacki, M.; Drozdowski, M.; Chadzynski, T. Associations of Dietary Patterns and Metabolic-Hormone Profiles with Breast Cancer Risk: A Case-Control Study. Nutrients 2018, 10, 2013. [CrossRef]

166. Wellberg, E.A.; Checkley, L.A.; Giles, E.D.; Johnson, S.J.; Oljira, R.; Wahdan-Alaswad, R.; Foright, R.M.; Dooley, G.; Edgerton, S.M.; Jindal, S.; et al. The Androgen Receptor Supports Tumor Progression After the Loss of Ovarian Function in a Preclinical Model of Obesity and Breast Cancer. Horm. Cancer 2017, 8, 269-285. [CrossRef]

167. Dwyer, A.R.; Truong, T.H.; Ostrander, J.H.; Lange, C.A. 90 YEARS OF PROGESTERONE: Steroid receptors as MAPK signaling sensors in breast cancer: Let the fates decide. J. Mol. Endocrinol. 2020, 65, T35-T48. [CrossRef]

168. Panno, M.L.; Naimo, G.D.; Spina, E.; Ando, S.; Mauro, L. Different molecular signaling sustaining adiponectin action in breast cancer. Curr. Opin. Pharmacol. 2016, 31, 1-7. [CrossRef] 
169. Stelzer, G.; Rosen, N.; Plaschkes, I.; Zimmerman, S.; Twik, M.; Fishilevich, S.; Stein, T.I.; Nudel, R.; Lieder, I.; Mazor, Y.; et al. The GeneCards Suite: From Gene Data Mining to Disease Genome Sequence Analyses. Curr. Protoc. Bioinform. 2016, 54, 1-30. [CrossRef]

170. Mizokami, A.; Gotoh, A.; Yamada, H.; Keller, E.T.; Matsumoto, T. Tumor necrosis factor-alpha represses androgen sensitivity in the LNCaP prostate cancer cell line. J. Urol. 2000, 164, 800-805. [CrossRef]

171. Jenks, M.Z.; Fairfield, H.E.; Johnson, E.C.; Morrison, R.F.; Muday, G.K. Sex Steroid Hormones Regulate Leptin Transcript Accumulation and Protein Secretion in 3T3-L1 Cells. Sci. Rep. 2017, 7, 8232. [CrossRef]

172. Fruhbeck, G. Intracellular signalling pathways activated by leptin. Biochem. J. 2006, 393, 7-20. [CrossRef] [PubMed]

173. Liao, R.S.; Ma, S.; Miao, L.; Li, R.; Yin, Y.; Raj, G.V. Androgen receptor-mediated non-genomic regulation of prostate cancer cell proliferation. Transl. Androl. Urol. 2013, 2, 187-196. [CrossRef] [PubMed]

174. Pietri, E.; Conteduca, V.; Andreis, D.; Massa, I.; Melegari, E.; Sarti, S.; Cecconetto, L.; Schirone, A.; Bravaccini, S.; Serra, P.; et al. Androgen receptor signaling pathways as a target for breast cancer treatment. Endocr. Relat. Cancer 2016, 23, R485-R498. [CrossRef] [PubMed]

175. Chen, T.; Wang, L.H.; Farrar, W.L. Interleukin 6 activates androgen receptor-mediated gene expression through a signal transducer and activator of transcription 3-dependent pathway in LNCaP prostate cancer cells. Cancer Res. 2000, 60, $2132-2135$.

176. De Miguel, F.; Lee, S.O.; Onate, S.A.; Gao, A.C. Stat3 enhances transactivation of steroid hormone receptors. Nucl. Recept. 2003, 1, 3. [CrossRef]

177. Gupta, N.; Mayer, D. Interaction of JAK with steroid receptor function. JAKSTAT 2013, 2, e24911. [CrossRef]

178. Hobisch, A.; Eder, I.E.; Putz, T.; Horninger, W.; Bartsch, G.; Klocker, H.; Culig, Z. Interleukin-6 regulates prostate-specific protein expression in prostate carcinoma cells by activation of the androgen receptor. Cancer Res. 1998, 58, 4640-4645.

179. Hosney, M.; Sabet, S.; El-Shinawi, M.; Gaafar, K.M.; Mohamed, M.M. Leptin is overexpressed in the tumor microenvironment of obese patients with estrogen receptor positive breast cancer. Exp. Ther. Med. 2017, 13, 2235-2246. [CrossRef]

180. Fiorio, E.; Mercanti, A.; Terrasi, M.; Micciolo, R.; Remo, A.; Auriemma, A.; Molino, A.; Parolin, V.; Di Stefano, B.; Bonetti, F.; et al. Leptin/HER2 crosstalk in breast cancer: In vitro study and preliminary in vivo analysis. BMC Cancer 2008, 8, 305. [CrossRef]

181. Ochsner, S.A.; Abraham, D.; Martin, K.; Ding, W.; McOwiti, A.; Kankanamge, W.; Wang, Z.; Andreano, K.; Hamilton, R.A.; Chen, Y.; et al. The Signaling Pathways Project, an integrated 'omics knowledgebase for mammalian cellular signaling pathways. Sci. Data 2019, 6, 252. [CrossRef]

182. Seidel, H.M.; Milocco, L.H.; Lamb, P.; Darnell, J.E., Jr.; Stein, R.B.; Rosen, J. Spacing of palindromic half sites as a determinant of selective STAT (signal transducers and activators of transcription) DNA binding and transcriptional activity. Proc. Natl. Acad. Sci. USA 1995, 92. [CrossRef]

183. Szyszka, M.; Paschke, L.; Tyczewska, M.; Jopek, K.; Celichowski, P.; Milecka, P.; Sultanova, G.; Stelcer, E.; Malinska, A.; Malendowicz, L.K.; et al. Analysis of Transcriptome, Selected Intracellular Signaling Pathways, Proliferation and Apoptosis of LNCaP Cells Exposed to High Leptin Concentrations. Int. J. Mol. Sci. 2019, 20, 5412. [CrossRef] 